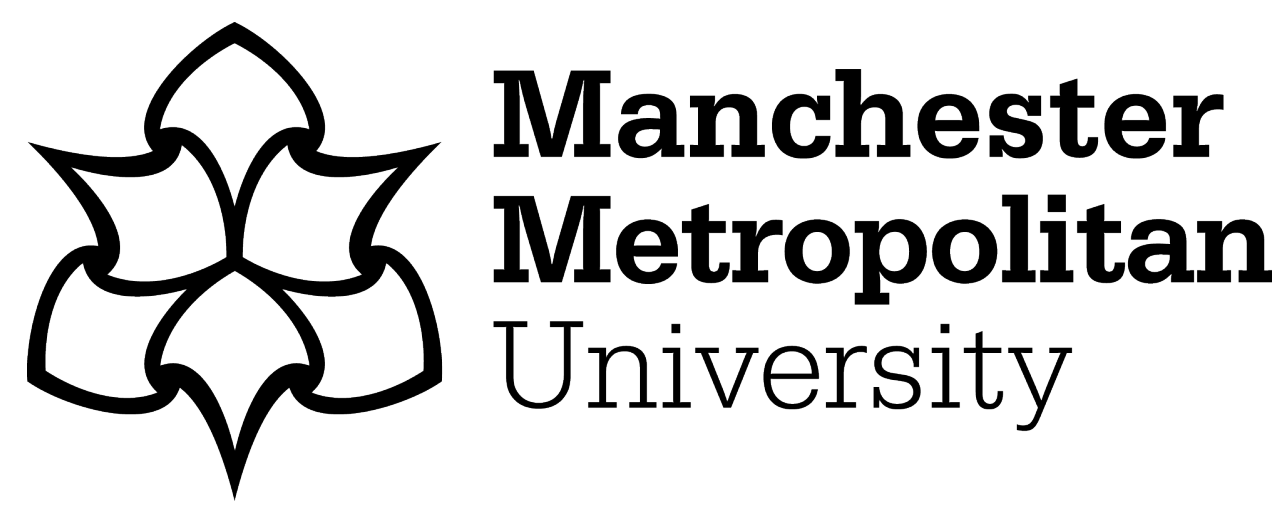

Crowley, JP (2014) 'Beyond the universal soldier: combat trauma in classical antiquity'. In: Combat trauma and the Greeks. The New Antiquity . Palgrave Macmillan, pp. 105-130. ISBN 9781137398857

Downloaded from: https://e-space.mmu.ac.uk/619424/

Publisher: Palgrave Macmillan

Please cite the published version 


\section{Beyond the Universal Soldier: Combat Trauma in Classical Antiquity}

\subsection{Introduction}

Like an epistemological echo of Donovan's famous song The Universal Soldier, the belief that the combatant's susceptibility to post-traumatic stress disorder/combat stress injury ${ }^{1}$ is diachronically universal is slowly gaining ground. ${ }^{2}$ Gabriel, for instance, argues that the experience of close-quarters battle would leave ancient armies burdened with thousands of psychological causalities. ${ }^{3}$ Shay offers an influential reading of the Iliad and the Odyssey as tales of both Achilles' and Odysseus' adverse psychological reactions to intense combat. ${ }^{4}$ Tritle argues, similarly, that Epizēlos, the uninjured Athenian hoplite who, according to Herodotus, went blind during the battle of Marathon, was suffering from conversion disorder, ${ }^{5}$ that Aristodemos' voluntary death during the battle of Plataea was motivated by survivor guilt, ${ }^{6}$ Xenophon's portrait of the Spartan

\footnotetext{
${ }^{1}$ This terminology, of course, reflects not only the value judgments attracted by this contentious subject, but also the breadth of human experience it covers (see, for instance, Shay's foreword to Figley and Nash's excellent edited volume Combat Stress Injury: Theory, Research, and Management (London, 2007), as well as W. Nash, 'Combat/Operational Stress Adaptations and Injuries', pp.33-63, in the same volume). For the sake of analytical clarity, and to avoid the confusion entailed by the adoption of often indistinct and overlapping typologies (such as combat related PTSD, combat shock, battle fatigue, perpetration induced PTSD etc), this article uses both terms as shorthand for the full range of adverse psychological reactions to combat.

${ }^{2}$ See B. Shephard, A War of Nerves: Soldiers and Psychiatrists in the Twentieth Century (Cambridge, Massachusetts, 2001), pp.385-99, and esp. D. Summerfield, 'A Critique of Seven Assumptions behind Psychological Trauma Programmes in War-affected Areas', Social Science and Medicine, Vol.48 (1999), pp.1449-62, which both challenges the presumption that PTSD is universal and context independent, and the Western psychological neo-colonialism that underpins it. For further discussion specific to the ancient world, see A. Melchior, 'Caesar in Vietnam: Did Roman Soldiers Suffer from Post-Traumatic Stress Disorder?' G\&R, Vol.58 (2011), pp.209-33.

${ }^{3}$ R. Gabriel, Soldiers' Lives Through History: The Ancient World (London, 2007), pp.12-15.

4 J. Shay, Achilles in Vietnam: Combat Trauma and the Undoing of Character (New York, 1995), Odysseus in America: Combat Trauma and the Trials of Homecoming (New York, 2002).

${ }^{5}$ Hdt. VI.117.2-3, with L. Tritle, From Melos to My Lai: War and Survival (London, 2000), p.64.

${ }^{6}$ Hdt. IX.71.1-4; cf. I.82.1-8; VII.231.1-232.1, IX.71.1-4; Paus. II.38.5; Thuc. V.41.2, with Tritle, From Melos to My Lai, pp.74-7.
} 
commander Clearchos is the description of a man suffering from PTSD, ${ }^{7}$ and that the unnamed individuals described by Gorgias who were terrified by the sight of warriors armed for combat, as well as those driven mad by the frightful things they had seen, were traumatised by their experiences of war. ${ }^{8}$ Naturally, such retrospective diagnoses are not restricted to ancient Greece. The concept of PTSD/CSI has been applied to individuals in $17^{\text {th }}$ century China, ${ }^{9}$ Pepys' diary, ${ }^{10}$ Shakespeare ${ }^{11}$ and even in the Bible. ${ }^{12}$

Typically, such retrospective diagnoses rest on an implicit belief in historically transcendental human equivalence, that is to say, that since modern humans are the equivalent of ancient humans, they are not only both equally susceptible to PTSD, but the presence or absence thereof can be detected by the same diagnostic criteria, currently embodied in $D S M-V .^{13}$ This view has already been accepted by many leading theorists

\footnotetext{
${ }^{7}$ Xen. Anab. II.6.1-16, with Tritle, From Melos to My Lai, pp.55-78. Consider also L. Tritle, 'Hector's Body: Mutilation of the Dead in Ancient Greece and Vietnam', $A H B$, Vol.11 (1997), pp.123-36.

${ }^{8}$ Gorg. Hel. 15-17, with L. Tritle, 'Gorgias, the Encomium of Helen and the Trauma of War', Clio's Psyche, Vol.16 (2009), pp.195-9. Additional discussion of this intriguing text can also be found in Tritle's $A$ New History of the Peloponnesian War (Oxford, 2010), pp. 158-60, as well as his own contribution to this volume ("'Ravished Minds" in the Ancient World') and that offered by Raaflaub ('War and the City: The Brutality of War and its Impact on the Community').

${ }^{9}$ L. Struve, 'Confucian PTSD: Reading Trauma in a Chinese Youngster's Memoir of 1653', History and Memory, Vol.16 (2004), pp.14-31.

${ }^{10}$ R. Daly, 'Samuel Pepys and Post-Traumatic Stress Disorder', The British Journal of Psychiatry, Vol.143 (1983), pp.64-8. Interestingly, although Daly acknowledges the possibility that PTSD is a historicallycontingent socio-cultural artefact, his diagnosis of Pepys leads him to accept (p.67) 'the temporal constancy of post-traumatic stress disorder.'

${ }^{11}$ M. Trimble, 'Post-traumatic Stress Disorder: History of a Concept', in C. Figley (ed.), Trauma and its Wake I: The Study and Treatment of Post-Traumatic Stress Disorder (New York, 1985), pp.5-14.

${ }^{12}$ C. Haughn and John Gonsiorek, 'The Book of Job: Implications for Construct Validity of Posttraumatic Stress Disorder Diagnostic Criteria', Mental Health, Religion and Culture, Vol.12 (2009), pp.833-45.

13 An acronym referring to the $5^{\text {th }}$ edition of the American Psychiatric Association's Diagnostic and Statistical Manual of Mental Disorders (Washington, 2013). Scholarship which predates this publication naturally refers to earlier editions, namely DSM-III (1980) and DSM-IV (1994). For the evolution of the diagnostic criteria set out in both, as well as the controversial revisions now embodied in DSM- $V$, see Shephard, A War of Nerves, pp.355-68, with A. Adler et al., 'A2 Diagnostic Criterion for Combat-Related Posttraumatic Stress Disorder', Journal of Traumatic Stress, Vol.21 (2008), pp.301-8; B. Gersons and I. Carlier, 'Post-Traumatic Stress Disorder: The History of a Recent Concept', The British Journal of Psychiatry, Vol.161 (1992), pp.742-8; P. Schnurr, 'The First 20 Years', Journal of Traumatic Stress, Vol.21 (2008), pp.1-2, 'The Changing Face of PTSD Diagnosis', Journal of Traumatic Stress, Vol.22 (2009), pp.1-2, 'PTSD 30 Years On', Journal of Traumatic Stress, Vol.23 (2010), pp.1-2.
} 
and clinicians, ${ }^{14}$ and given the ongoing exponential increase in publications about PTSD/CSI, it seems likely that such studies will continue to proliferate until the universalist premise that underpins them becomes dogma. ${ }^{15}$ Yet, whilst this premise, that susceptibility to PTSD/CSI is diachronically universal, to put the matter in Popperian terms, cannot be verified by the parade of white swans it has generated, it can be refuted by the production of one single black swan, and it is the aim of this article to provide just such a creature. ${ }^{16}$

\subsection{Methodology}

The methodology usually adopted by the universalists is characterised by the search for supporting sources which appear to describe conduct which could conceivably fit the current diagnostic criteria for PTSD/CSI, which, once identified, are deployed in support of a retrospective diagnosis thereof. ${ }^{17}$ This methodology is admirably direct, yet, it inevitably produces subjective and unfalsifiable readings of isolated pieces of ancient evidence, ${ }^{18}$ and more importantly, it fails to recognise that PTSD/CSI results from the

\footnotetext{
${ }^{14}$ Consider, for instance, C. March and N. Greenberg, 'The Royal Marines' Approach to Psychological Trauma' in C. Figley and W. Nash (eds.), Combat Stress Injury: Theory, Research, and Management (London, 2007), pp.247-60, also, from the same volume, W. Nash, 'Combat/Operational Stress Adaptations and Injuries', pp.33-63; J. Spira, J. Pyne and B. Wiederhold, 'Experiential Methods in the Treatment of Combat PTSD', pp.205-18.

${ }^{15}$ Emergence of dogma: Melchior, 'Caesar in Vietnam', pp.209-23. Proliferation: Schnurr, 'PTSD: 30 Years On', pp.1-2, which demonstrates that this increase in interest, reflected in the number of PTSDfocused publications, which grew from only 900 in 1984 to nearly 9000 in 2010, is simply phenomenal. Furthermore, as the source of these figures reveals (the United States' Department of Veterans' Affairs' Published International Literature On Traumatic Stress (PILOTS) Database, which can be found at www.ptsd.va.gov), this trend is continuing.

${ }^{16}$ A methodology famously outlined by Popper in The Logic of Scientific Discovery (London, 1959).

${ }^{17}$ For paradigmatic examples, see Daly, 'Samuel Pepys and Post-Traumatic Stress Disorder', pp.64-8; Tritle, From Melos to My Lai, p.64, pp.74-7, pp.123-36.

${ }^{18}$ Tritle's interpretation of Aristodemos' death (From Melos to My Lai, pp.74-7) is an excellent example. His interpretation is perceptive, persuasive and consistent with the ancient evidence, but so too is its most obvious competitor, that Aristodemos chose a glorious death in combat instead of a life degraded by the irrevocable destruction of his social status (cf. Xen. Lac. Pol. IX.1.6, with additional discussion in J. Crowley, The Psychology of the Athenian Hoplite: The Culture of Combat in Classical Athens (Cambridge, 2012), pp.86-8, pp.106-7, pp.117-19.
} 
interaction of two variables, namely the human being and his or her environment. ${ }^{19}$ This fact is critical, of course, because neither variable is historically transcendental: the attitudes and core beliefs adopted by combatants change, as does the socio-military environment in which they fight. This, naturally, allows for the possibility that although the modern combatant and his socio-military environment combine to produce a susceptibility to PTSD/CSI, a very different historically specific combination could just as easily reduce, suppress or even eliminate that susceptibility.

To investigate this possibility, this article will contrast two combatants and their respective environments. Since the current diagnostic criteria for PTSD/CSI directly derives from the experiences of U.S. Vietnam veterans, the first of these combatants has to be the modern, specifically $20^{\text {th }}$ Century, American infantryman. ${ }^{20}$ Similarly, since the American infantryman's adverse psychological reactions to combat have been retrospectively applied to ancient Greece, and since he is one of the few warriors from classical antiquity for which a reasonable degree of narrative evidence survives, the

\footnotetext{
${ }^{19}$ C. Aldwin, Stress, Coping, and Development: An Integrative Perspective (New York, 1994); R. Lazarus, 'Cognitive-motivational-relational theory of Emotion' in Y. Hanin (ed.), Emotions in Sport (Champaign, Illinois, 2000), pp.39-64; J. Szalma, 'Individual Differences in Stress Reaction' in P. Hancock and J. Szalma (eds.), Performance under Stress (Burlington, Vermont, 2008), pp.323-57, also Nash, 'The Stressors of War' in C. Figley and W. Nash (eds.), Combat Stress Injury: Theory, Research, and Management (London, 2007), pp.11-31, with 'Combat/Operational Stress Adaptations and Injuries', pp.3363.

${ }^{20}$ See above, Section 1.1, n.13, with B. Moore and G. Reger, 'Historical and Contemporary Perspectives of Combat Stress and the Army Combat Stress Control Team' in C. Figley and W. Nash (eds.), Combat Stress Injury: Theory, Research, and Management (London, 2007), pp.161-81, also Shephard, A War of Nerves, esp. pp.355-68. Of course, American soldiers were not fundamentally dissimilar to those troops fielded by other Western nations, nor were their responses to the experience of combat. Earlier drafts of this paper, in fact, proposed the 'Western soldier' as the modern point of comparison, but the American soldier was eventually adopted for three reasons: firstly, it was his experiences that generated the current debate regarding adverse reactions to combat; secondly, the available evidence overwhelming relates to American troops; thirdly, it was hoped the focus on one specific combatant during one specific time period would help minimise, to some degree at least, the kind of analytically unhelpful generalisations unavoidably entailed by encompassing different cultures and time periods. Similar reasons explain why the Athenian hoplite was adopted as the ancient point of comparison, instead of a more general 'Greek' warrior.
} 
second combatant will be the Athenian hoplite. ${ }^{21}$ To maximise the force of the comparison and to avoid the charge that a modern apple is being compared to an ancient orange, these combatants have been chosen because they perform exactly the same tactical role, that is to say it is their grim task to close with and kill the enemy.

To ensure methodological clarity, the analytical distinction between the individual and his environment will be maintained throughout. Accordingly, examination of both the modern and ancient paradigms will focus on the combatant's core norms and values, since they determine what is or is not traumatic, as well as the three most pertinent aspects of the combatant's environment, namely, the social environment, the tactical environment and lastly, the technological environment. Thereafter, the susceptibility of both paradigms to PTSD/CSI will be assessed and then compared. Finally, this article will conclude by considering the implications of this comparison for the continued viability of the universalist position.

\subsection{The American Infantryman and his Environment}

Obviously, it is important to acknowledge that significant points of continuity exist between the two historical case studies examined by this article. Like the American infantryman, the Athenian hoplite found the experience of combat intensely frightening, ${ }^{22}$

\footnotetext{
${ }^{21}$ See above, Section 1.1, ns.3-8. For the nature of hoplite combat, see esp. A. Schwartz, Reinstating the Hoplite: Arms, Armour and Phalanx Fighting in Archaic and Classical Greece (Stuttgart, 2009), also J. Anderson, Military Theory and Practice in the Age of Xenophon (London, 1970); G. Grundy, Thucydides and the History of his Age (London, 1911), pp.267-73; V. Hanson, The Western Way of War: Infantry Battle in Classical Greece (London, 2000). Note, however, the competing model ably advanced by H. van Wees in Greek Warfare: Myths and Realities (London, 2004), esp. pp.184-97. For a summary of the debate between adherents of both positions, see Crowley, The Psychology of the Athenian Hoplite, pp.53-62.

22 A wide convergence of evidence attests not only to the experience of fear (Aristoph. Birds 289-90, 147081, Clouds 350-5, Peace 444-6, 673-8, 1172-85, 1295-1304, Wasps 10-30, 592, 820-5; Eur. Bacch. 303-4; Lys. X.8-9, 12, 21-4, XVI.17; Thuc. IV.34.7, VII.80.3; Tyrt. XI.22; Xen. Hell. IV.3.17), but also to the appearance of its physical manifestations (Aristoph. Kn. 1055-6, Peace 239-41, 1179-81; Hdt. VII.231;
} 
and like his modern counterpart, he too suffered from exposure to the elements and all the other physical hardships associated with active service. ${ }^{23}$ Nevertheless, the American infantryman carried into combat a highly specific set of norms and values shaped, regardless of personal belief, by the pervasive influence of Christianity. ${ }^{24}$ Although once a fighting religion, by the outbreak of the Second World War, Christianity's former belligerence had been replaced by a non-violent ideal stressing personal moral conduct, ${ }^{25}$ mercy, love, and respect for human life, ${ }^{26}$ with such principles most forcefully expressed in the Christian duty to 'turn the other cheek' and to 'love thy neighbour', as well as, of course, by the $6^{\text {th }}$ Commandment, popularly translated as 'thou shalt not kill., 27

Like the norms and values he adopted, the American infantryman's social environment was just as distinctive. In the U.S. Army and Marine Corps, men served in military units comprised of complete strangers drawn from diverse geographical locations and socio-economic circumstances. ${ }^{28}$ Naturally, in such a social environment, cohesion required time to develop. However, in American combat units, which, during the period under discussion, demonstrated a particular propensity for both poor performance in

Hom. Il. XIII.279-83; Plut. Ages. XXX.2-4, Arat. XXIX.5; Polyaen. Strat. III.4.8; Thuc. V.10.8; Xen. Hiero VI.3.7.

${ }^{23}$ Aristoph. Peace 348; Thuc. II.58.1-3, VII.47.1-3, 59.2-87.6; Xen. Hunt. XI.2, Lac. Pol. IV.7.

${ }^{24}$ S. Marshall, Men Against Fire: The Problem of Battle Command (Oklahoma, 2000), p.78, also R. Holmes, Acts of War (London, 2003), p.58, p.71; J. McManus, The Deadly Brotherhood: The American Combat Soldier in World War II (Novato, California, 1998), pp.154-5, pp.229-35, p.279; S. Stouffer et al., Studies in Social Psychology in World War Two, Volume. II: The American Soldier: Combat and its Aftermath (Princeton, 1949), pp.172-191.

${ }^{25}$ B. Ehrenreich, Blood Rites: Origins and History of the Passions of War (London, 1997), p.163, pp.165174; M. Hogg and G. Vaughan, Social Psychology (Harlow, 2002), pp.460-2; Holmes, Acts of War, p.289.

${ }^{26}$ J. Bourke, An Intimate History of Killing: Face-to-Face Killing in Twentieth Century Warfare (London, 1999), p.224; Ehrenreich, Blood Rites, pp.165-6; J. Keegan, A History of Warfare (London, 1993), pp.48-9.

${ }^{27}$ Deut. V.4-21; Ex. XX.1-17; Luke 6.31; Mark XII.31; Matt. VII.12, with further discussion in Bourke, An Intimate History of Killing, pp.215-41.

${ }^{28}$ See esp. Holmes, Acts of War, p.82, pp.79-93. For extended discussion and an extremely valuable collection of evidence, see S. Stouffer et al., Studies in Social Psychology in World War Two, Volume I: The American Soldier: Adjustment during Army Life (Princeton, 1949). 
combat and PTSD/CSI, the process of inter-personal affiliation was retarded by the operation of three mutually reinforcing policies. ${ }^{29}$

The first of these policies was individual replacement, consequent to which, for instance, units which sustained casualties during World War Two were not withdrawn from the line and reinforced, as was usually the case with the armies of Britain and Germany, ${ }^{30}$ but kept up to strength by the allocation of individual replacements drawn from a replacement depot. ${ }^{31}$ The second was individual rotation, which found its most famous manifestation during the Vietnam War. This policy operated on the principle that a soldier's ability to endure combat was finite, ${ }^{32}$ and consequently, during the Vietnam War, soldiers were limited to a twelve-month tour of duty, ${ }^{33}$ with officers serving only six in order to facilitate the proliferation of command experience. ${ }^{34}$ The third policy, aimed at increasing operational efficiency, assigned each ostensibly interchangeable and transposable combatant an M.O.S., a military occupational speciality, by which the

\footnotetext{
${ }^{29}$ R. Gabriel and P. Savage, Crisis in Command: Mismanagement in the Army (New York, 1978), pp.x-9, pp.29-41, p.50, pp.55-8; W. Henderson, Cohesion: The Human Element in Combat: Leadership and Societal Influence in the Armies of the Soviet Union, the United States, North Vietnam, and Israel (Washington, 1985), pp.31-2. See also S. Wesbrook, 'The Potential for Military Disintegration' in S. Sarkesian (ed.), Combat Effectiveness: Cohesion, Stress, and the Volunteer Military (London, 1980), pp.274-6.

${ }^{30}$ E. Shils and M. Janowitz, 'Cohesion and Disintegration in the Wehrmacht in World War II', Public Opinion Quarterly, Vol.12 (1948), pp.287-8; M. van Creveld, Fighting Power: German and U.S. Army Performance, 1939-1945 (Westport, 1982), pp.42-60, pp.74-9, pp.90-1, also R. Glenn, Reading Athena's Dance Card: Men Against Fire in Vietnam (Annapolis, 2000), pp.85-6.

${ }^{31}$ Stouffer et al., Studies in Social Psychology II, pp.242-89; van Creveld, Fighting Power, pp.75-7, pp.901, pp.166-8.

${ }^{32}$ See esp. C. Wilson, The Anatomy of Courage (London, 1987), p.xvi, also Nash, 'Combat/Operational Stress Adaptations and Injuries', pp.48-59; Shephard, A War of Nerves, pp.143-60.

${ }^{33}$ Extended to thirteen months for marines, for which see G. Lewy, 'The American Experience in Vietnam' in S. Sarkesian (ed.), Combat Effectiveness: Cohesion, Stress, and the Volunteer Military (London, 1980), pp.102-3.

${ }^{34}$ Gabriel and Savage, Crisis in Command, pp.3-28, pp.70-2; A. Hoiberg, 'Military Staying Power' in S. Sarkesian (ed.), Combat Effectiveness: Cohesion, Stress, and the Volunteer Military (London, 1980), pp.232-4; Lewy, 'The American Experience in Vietnam', pp.102-3. Note, however, the argument offered by Gabriel and Savage (Crisis in Command, pp.3-28, pp.51-96), namely that this policy, despite its stated aim, was actually motivated by careerism.
} 
military matched man to task, ${ }^{35}$ consequent to which individuals were assigned and reassigned whenever and wherever units required their services. ${ }^{36}$

Whatever their current combat assignment, these individuals operated in a tactical environment determined by modern weapons systems, particularly the rifle, machine gun and the artillery piece, which together produce what military theorists call the dispersed battlefield. ${ }^{37}$ This deadly arena, traversed by red hot, razor sharp shrapnel and highvelocity gunfire, forced the soldier to seek safety in cover and concealment, and most importantly, to reduce the lethal affects of explosive and automatic weapons, by remaining, at all times, physically distant from his comrades. ${ }^{38}$

Of course, modern weapons not only combine to produce a highly distinctive tactical environment, they, together with supporting military assets and equipment, also combine to produce a highly distinctive technological environment. Therein, the American infantryman faced a range of threats, not only from other similarly armed and equipped infantrymen, but also from armour, close-air support, indirect fire weapons such as mortars and artillery pieces, not to mention tactical obstacles like landmines and improvised explosive devices. ${ }^{39}$ In doing so, he was supported by sophisticated logistical

\footnotetext{
${ }^{35}$ W. Hauser, 'The Will to Fight' in S. Sarkesian (ed.), Combat Effectiveness: Cohesion, Stress, and the Volunteer Military (London, 1980), pp.187-8, pp.204-5; Hoiberg, 'Military Staying Power', pp.213-14.

${ }^{36}$ Gabriel and Savage, Crisis in Command, pp.117-43; Henderson, Cohesion, p.18; Hauser, 'The Will to Fight', pp.194-5, pp.204-5; A. Kellet, Combat Motivation: The Behavior of Soldiers in Battle (London, 1982), p.43; L. Sorley, 'Prevailing Criteria: A Critique' in S. Sarkesian (ed.), Combat Effectiveness: Cohesion, Stress, and the Volunteer Military (London, 1980), pp.73-89; Wesbrook, 'The Potential for Military Disintegration', pp.266-7.

${ }^{37}$ Bourke, An Intimate History of Killing, p.92; J. Gray, The Warriors: Reflections on Men in Battle (London, 1998), p.136; Marshall, Men Against Fire, p.60.

${ }^{38}$ Consider, for instance, the British Army's Section Battle Drills, reproduced in The Volunteer's Pocket Book (Beverley, 1991), pp.110-12, with further discussion in Bourke, An Intimate History of Killing, p.77; Glenn, Introduction to Marshall's Men Against Fire, p3; Marshall, Men Against Fire, p.22, p.46, p.145; W. van Zanten, Don't Bunch Up (and Some Notable Exceptions): One Marine's Story (Connecticut, 1993), pp.9-10, p.15. For the grim consequences of transgression, see, for example, G. Sajer, The Forgotten Soldier (London, 1991), pp.321-4.

${ }^{39}$ See above, Section 2.1, n.38.
} 
systems and technological aids. His personal load carrying equipment allowed for the efficient carriage of considerable amounts of his three basic staples, food, water and ammunition, and when his supplies were expended, he could be resupplied in the field, usually, in the final quarter of the $20^{\text {th }}$ Century, by helicopter. Consequently, the American infantryman could maintain contact with the enemy for extended periods, and since, from the Vietnam period onwards, he was typically equipped with tactical nightvision aids, he could also do so around the clock. ${ }^{40}$

\subsection{The American Infantryman's Susceptibility to PTSD/CSI}

It seems obvious, therefore, that the $20^{\text {th }}$ Century American infantryman entered combat with a historically-specific set of norms and values, and he operated in a historically-specific social, tactical and technological environment. What is not obvious, however, is that his pre-battle socialisation and every aspect of his environment combined to enhance his susceptibility to PTSD/CSI.

To start with, the American infantryman's Christianised norms and values, stressing peace, mercy and the sanctity of human life, were so stunningly incongruent with his tactical role, to close with and kill his enemy, that, as Marshall observed, during World War Two, such beliefs constituted a 'handicap'41 which inhibited the infantryman's ability to fight and to kill. ${ }^{42}$ Naturally, this inhibition was militarily undesirable, and during the period under consideration, the U.S. military employed four

\footnotetext{
${ }^{40}$ Holmes, Acts of War, pp.115-35; Nash, 'The Stressors of War', pp.18-22; M. van Creveld, 'Technology and War II: From Nuclear Stalemate to Terrorism' in Charles Townshend (ed.), The Oxford History of Modern War (Oxford, 2005), pp.341-63, also MCRP (Marine Corps Reference Publication) 6-11C (Washington, 2000), pp.55-75. For an overview of modern infantry combat and the role of rotary-wing aircraft, see L. Cacutt, Combat (London, 1992), pp.11-55, pp.122-57.

${ }^{41}$ Marshall, Men Against Fire, p.67, pp.76-9.

${ }^{42}$ Marshall, Men Against Fire, p.78; Stouffer, Studies in Social Psychology II, p.77, with further discussion in R. Baron \& D. Byrne, Social Psychology (New Delhi, 2004), p.453; Bourke, An Intimate History of Killing, p.224, p.247, p.251, p.260; Ehrenreich, Blood Rites, p.10, pp.165-174; Hogg \& Vaughan, Social Psychology, p.460-1; Nash, 'Combat/Operational Stress Adaptations and Injuries', pp.48-59.
} 
main techniques aimed at overcoming it. Firstly, it endeavoured to re-socialise its recruits, that is to say, to engineer the elimination of incongruous norms and values and their replacement with those designed to facilitate combat. ${ }^{43}$ Secondly, it attempted to desensitise the soldier, ${ }^{44}$ for instance, through the deification of killing, manifested by the worship of the 'spirit of the bayonet'45 and the chanting of mantras such as 'kill, kill, kill' ${ }^{46}$ Thirdly, it supported its soldiers' inclination to deny their lethal activities, by encouraging them to see combat as nothing more than a series of drills identical to those carried out during training. ${ }^{47}$ Fourthly, as Grossman observes, after particular poor performance during the Second World War, it sought to bypass any resistance to killing by embedding Pavlovian/Skinnerian conditioning techniques into skill at arms training, which henceforth presented the soldier with a stimulus in the form of a pop-up, manshaped target, for which the conditioned response was swift and accurate engagement,

\footnotetext{
${ }^{43}$ S. Bidwell, Modern Warfare: A Study of Men, Weapons and Theories (London, 1973), p.1; Glenn, Reading Athena's Dance Card, pp.1-126; D. Grossman, On Killing: The Psychological Cost of Learning to Kill in War and Society (London, 1996), pp.xxiii-xxii, pp.1-4, pp.249-61; Bourke, An Intimate History of Killing, pp.69-102; Henderson, Cohesion, p.18, p.49, p.51, pp.75-6; Holmes, Acts of War, pp.7-18, pp.3673, pp.136-75, pp.204-69, pp.270-359; Kellet, Combat Motivation, pp.67-78; P. Caputo, A Rumor of War (New York, 1977), pp.8-10; B. Shalit, The Psychology of Conflict and Combat (London, 1988), p.110; Stouffer, Studies in Social Psychology I, pp.472-3, Studies in Social Psychology II, pp.85-6. For notable examples, see Caputo, A Rumor of War, pp.8-10, p.36; T. O'Brien, If I Die in a Combat Zone (London, 1995), p.51; S. Sassoon, Memoirs of an Infantry Officer (London, 1966), pp.16-17.

${ }^{44}$ Grossman, On Killing, pp.248-261, with Section 2.2, n.43, also Bidwell, Modern Warfare, pp.61-3; P. Watson, War on the Mind: The Military Uses and Abuses of Psychology (Harmondsworth, 1980), pp.181-3. For the concept of 'battle inoculation' generally, see Bourke, An Intimate History of Killing, pp.87-8; Holmes, Acts of War, pp.53-4; Watson, War on the Mind, pp.141-44.

${ }^{45}$ See, for example, O'Brien, If I Die in a Combat Zone, p.51; cf. Sassoon, Memoirs of an Infantry Officer, pp.16-17, with additional discussion in Bourke, An Intimate History of Killing, pp.87-8, pp.92-3, pp.153-4.

${ }^{46}$ Grossman, On Killing, pp.251-2. For instance, in an attempt to enhance their ability to kill in the jungles of South Vietnam, Caputo's hatchet-wielding and war-crying sergeant ordered his nervous recruits to chant 'ambushes are murder and murder is fun.' See A Rumor of War, p.36.

${ }^{47}$ Grossman, On Killing, p.233, p.256; cf. Bourke, An Intimate History of Killing, pp. 225-35; Holmes, Acts of War, p.366. This, of course, would also explain the widely attested calls of 'endex' (military shorthand for end of exercise) by British troops when hostilities ceased on the Falklands, for which see V. Bramley, Excursion to Hell: The Battle for Mount Longdon (London, 1991), p.173; cf. Gray, The Warriors, p.136.
} 
positively reinforced through the fall of the target, as the enemy 'died', and thereafter through progression in rank and associated privilege. ${ }^{48}$

Such techniques, during combat, when extreme stress often impairs high-level cognition, enhanced the American infantryman's ability to overcome his inhibition and kill, but they did so only at considerable psychological cost. ${ }^{49}$ By killing, the American infantryman committed an irreversible act that transgressed his core values, and as psychologists recognise, such psychologically damaging transgressions are often closely associated with subsequent diagnoses of PTSD/CSI. ${ }^{50}$

The successful performance of his battlefield role, therefore, was psychologically toxic to the American infantryman, as, of course, was the social environment in which he was compelled to discharge it. As Schachter's experiments have demonstrated, when human beings perceive danger, they experience feelings of anxiety which stimulate the desire to affiliate with other human beings. ${ }^{51}$ This inter-personal affiliation then reduces anxiety, and in socio-military contexts, it enhances morale, endurance, psychological

\footnotetext{
${ }^{48}$ Grossman, On Killing, pp.xxiii-xxii, pp.1-4, p.177, pp.249-61, p.313; Watson, War on the Mind, pp.4957, pp.89-104. For Marshall's influence on these reforms, see Bourke, An Intimate History of Killing, pp.69-102; Holmes, Acts of War, pp.7-18, pp.36-73, pp.136-75, pp.204-69, pp.270-359, also Glenn's introduction to Marshall's Men Against Fire, pp.1-11, together with his own application of Marshall's theories in Reading Athena's Dance Card, pp.1-126.

49 Grossman, On Killing, pp.xviii, p.233, also D. Grossman and L. Christensen, On Combat: The Psychology of Deadly Conflict in War and Peace (New York, 2008), pp.2-137, with O'Brien, If I Die in a Combat Zone, pp.50-1 and Holmes, Acts of War, pp.41-2.

${ }^{50}$ Bourke, An Intimate History of Killing, esp. pp.221-71; Grossman, On Combat, pp.356-64; R. MacNair, Perpetration-Induced Traumatic Stress: The Psychological Consequences of Killing (Westport, Connecticut, 2002), esp. pp.1-29; S. Maguen et al., 'The Impact of Reported Direct and Indirect Killing on Mental Health Symptoms in Iraq War Veterans', Journal of Traumatic Stress, Vol.23 (2010), pp.86-90; Nash, 'Combat/Operational Stress Adaptations and Injuries', pp.48-59, 'The Stressors of War', pp.25-7; Shephard, A War of Nerves, pp.369-76; Shay, Odysseus in America, pp.19-34, pp.107-12, pp.231-41; Stouffer et al., Studies in Social Psychology II, p.77, pp.172-91, with extended discussion in Shay, Achilles in Vietnam.

${ }^{51}$ For these experiments, see S. Schatcher, The Psychology of Affiliation (Stanford, California, 1959), with Kellet, Combat Motivation, p.xix, pp.98-103, p.287, pp.320-1, also Ehrenreich, Blood Rites, pp.22-95; Henderson, Cohesion, p.108, p.163; Shalit, The Psychology of Conflict and Combat, p.159; Stouffer et al., Studies in Social Psychology II, p.96, pp.99-100, pp.130-49; Wilson, The Anatomy of Courage, p.127.
} 
resilience, and small-unit cohesion, thereby enabling the soldier to withstand challenges which would break an unaffiliated combatant. ${ }^{52}$

For the combatant, then, affiliation offers profound protection against psychological breakdown. Given time and social stability, the vast majority of modern Western soldiers affiliate easily with their peers, ${ }^{53}$ yet, the operation of individual replacement, individual rotation and the constant reassignments which resulted from the M.O.S. system effectively denied the American infantryman the same quality of opportunity. ${ }^{54}$ Instead, he operated in a social environment characterised by chronic personnel turbulence, which revealed its deleterious effects most graphically during the war from which, tellingly, the very concept of PTSD is derived: Vietnam. ${ }^{55}$ There, the operation of individual rotation and individual replacement resulted in a never-ending sequence of inexperienced officers to lead an ever-changing collection of troops whose incessant rotation and replacement inhibited affiliation precisely where it was needed most: in combat. ${ }^{56}$ Naturally, such a social environment was perfect for the proliferation

\footnotetext{
${ }^{52}$ C. A. du Picq, Battle Studies: Ancient and Modern Battle (Roots of Strategy Book 2: 3 Military Classics, Mechanicsburg, 1987), p.125, p.136; Ehrenreich, Blood Rites, pp.22-95; Glenn, Reading Athena's Dance Card, p.114; Kellet, Combat Motivation, p.xix, p.41, p.45, pp.98-101, pp.277-9, p.300, pp.320-1, p.331; McManus, The Deadly Brotherhood, pp.273-6, p.278, pp.286-8; Shalit, The Psychology of Conflict and Combat, p.115; Shils and Janowitz, 'Cohesion', pp.284-5, p.302; Stouffer et al., Studies in Social Psychology II, p.80, p.100, p.107, pp.130-49; van Creveld, Fighting Power, pp.91-100; Watson, War on the Mind, p.91; Wesbrook, 'The Potential for Military Disintegration', p.252; Wilson, The Anatomy of Courage, p.xvi, p.94, p.174.

${ }^{53}$ See above, Section 2.1, n.28, with additional discussion in Kellet, Combat Motivation, p.42, p.123, p.320; Stouffer et al., Studies in Social Psychology II, pp.278-80, and for one particularly swift example, see McManus, The Deadly Brotherhood, p.280.

${ }^{54}$ See above, Section 2.1, ns.29-36.

${ }^{55}$ See above, Section 1.1, n.13.

${ }^{56}$ Gabriel and Savage, Crisis in Command, pp.3-41, pp.50-96, also R. Beaumont and W. Snyder, 'Combat Effectiveness: Paradigms and Paradoxes' in S. Sarkesian (ed.), Combat Effectiveness: Cohesion, Stress, and the Volunteer Military (London, 1980), p.46; Glenn, Reading Athena's Dance Card, pp.84-108, pp.115-9; Hauser, 'The Will to Fight', pp.192-4, p.205; Henderson, Cohesion, p.18; Hoiberg, 'Military Staying Power', pp.231-4; Lewy, 'The American Experience in Vietnam', pp.102-3; Shalit, The Psychology of Conflict and Combat, p.170; cf. du Picq, Battle Studies, pp.122-3.
} 
of PTSD/CSI, and unfortunately for the American soldier, this profound propensity was further exacerbated by his tactical environment.

In combat, the affiliative desire generated by intense fear produces an irresistible longing for the psychological support offered by the close physical proximity of other human beings,${ }^{57}$ the most visible expression of which is the irrational tendency of modern troops to 'bunch' under fire. ${ }^{58}$ Since this increases the lethal effects of both explosive and automatic weapons, modern infantry tactics require troops to maintain their personal intervals, and when under effective enemy fire, to seek cover and concealment. ${ }^{59}$ This offers effective protection against enemy weapons, yet, as each soldier goes to ground, his unit, no matter how cohesive, is transformed into a collection of mutually isolated individuals who engage their enemy alone, not only denied the comfort offered by the close physical proximity of their peers but actually segregated from them, and therefore bereft of the benefits offered by their protective presence. This tactical environment, then, virtually ensured that the American infantryman was psychologically most vulnerable precisely at the point of severest psychological stress. ${ }^{60}$

Worse still, this psychological vulnerability was further enhanced by the technological environment in which the American infantryman operated. This presented the infantryman with a range of threats, to which, as Lazarus demonstrated, he could

\footnotetext{
${ }^{57}$ C. Cooley, Social Organization: A Study of the Larger Mind (London, 2005), pp.23-42; du Picq, Battle Studies, pp.110-14, p.125, p.141; Kellet, Combat Motivation, p.320; Marshall, Men Against Fire, p.41, p.141, p.145; W. Trotter, Instincts of the Herd in Peace and War (London, 1921), pp.140-3; Wesbrook, 'The Potential for Military Disintegration', pp.251-2. See also Section 2.2, n.51.

${ }^{58}$ Holmes, Acts of War, pp.24-5; Kellet, Combat Motivation, p.98, p.100, pp.320-1; McManus, The Deadly Brotherhood, p.276; Stouffer et al., Studies in Social Psychology II, pp.283-4; van Zanten, Don't Bunch Up, pp.9-10, p.15; cf. Thuc. V.71.1.

${ }^{59}$ See, for instance, the British Army's No.2 Section Battle Drill, reproduced in The Volunteer's Pocket Book, p.111; cf. G. Bransby, Her Majesty's Vietnam Soldier (London, 1992), p.13, with Section 2.1, ns.378, Section 2.2, n.58.

${ }^{60}$ Marshall, Men Against Fire, p.47, pp.124-7, p.129, with Section 2.2, n.52.
} 
respond in two very different ways, either taking direct action to remove or escape the threat, or, if this was not possible, by taking palliative action to reduce its stressful effects through denial, drugs, alcohol or humour. ${ }^{61}$ Obviously, the type of response adopted by the infantryman is largely determined by two variables, namely the kind of threat facing him and his personal capacity to counter it. Thus, for instance, the infantryman can employ direct action against other troops, that is to say, by killing, suppressing or breaking contact with them, but he is forced to rely on palliative action when under artillery bombardment, since his personal weapon cannot be employed against a target ten or more kilometres distant from his own position. ${ }^{62}$

This distinction is, of course, important because direct action removes the threat, and in consequence, it is psychologically benign. In contrast, palliative action leaves the combatant in contact with the noxious agent, and as a result, it is psychologically malignant. ${ }^{63}$ This explains why, during World War Two, as Stouffer and his colleagues discovered, American soldiers found the lethal threat presented by enemy crew-served weapons, such as MG34s and 42s, reasonably manageable, because they could respond with direction action, but they were intensely fearful of enemy artillery and air support, precisely because the only real response they had to this kind of threat was palliation. ${ }^{64}$ Naturally, this enhanced the American soldier's psychological vulnerability, because,

\footnotetext{
${ }^{61}$ R. Lazarus, Psychological Stress and the Coping Process (New York, 1966), with a good overview of this theory outlined in W. Buskist, N. Carlson and G. Martin, Psychology, (London, 2004), pp.723-4.

${ }^{62}$ See, esp. Holmes, Acts of War, pp.28-30, with Section 2.1, ns.37-8, and Section 2.2, n.59.

${ }^{63}$ Bourke, An Intimate History of Killing, p.159, pp.248-9; Holmes, Acts of War, pp.28-30, pp.139-40, pp.211-12, pp.230-2, p.255, p.261; J. Keegan, The Face of Battle: A Study of Agincourt, Waterloo and the Somme (London, 1976), pp.70-1; Kellet, Combat Motivation, p.256, p.277, p.300; F. Richardson, Fighting Spirit: A Study of the Psychological Factors in War (London, 1978), p.53; Shephard, A War of Nerves, pp.33-51; Watson, War on the Mind, pp.154-6; Wilson, The Anatomy of Courage, p.38. The obvious exception to this dichotomy is where direct action involves killing, in which case the psychological benefit derived from the removal of the threat is potentially tainted by the moral transgression entailed thereby (see Section 2.2, n.50).

${ }^{64}$ Stouffer et al., Studies in Social Psychology II, p.83, pp.232-41.
} 
against the most lethal threats he faced, the only response available to him was psychologically toxic.

This vulnerability was further aggravated by his extended exposure to combat. Typically well trained and equipped, and supported by a sophisticated logistical apparatus, he was able and often expected to maintain contact with the enemy for many months at a time. ${ }^{65}$ In addition, his ability to conduct operations during the hours of darkness ensured that the progressive exhaustion he experienced consequent to the physical and mental demands of extended campaigning were further compounded by sleep deprivation, which, as psychologists recognise, is a toxic combination which lowers the soldier's mental resilience and intensifies his vulnerability to psychological breakdown. $^{66}$

The American soldier, therefore, demonstrated a profound propensity for PTSD/CSI as a result of a convergence of historically-specific factors. Firstly, the Christianised norms and values he took to the battlefield ensured that the successful performance of his battlefield role was psychologically toxic. Secondly, his social environment reduced or even denied him the psychological benefits of protective affiliation. Thirdly, his tactical environment robbed him of the comfort he would otherwise have derived from the physical proximity of his peers and forced him to face his enemy alone, isolated and psychologically exposed. Fourthly, his technological environment presented him with threats which frequently required psychologically harmful responses, and the logistical and technological support he received during

\footnotetext{
${ }^{65}$ See above, Section 2.1, n.40.

${ }^{66}$ Grossman, On Combat, pp.14-29, On Killing, pp.69-73; Holmes, Acts of War, pp.115-35; Nash, 'The Stressors of War', pp.18-22; MCRP 6-11C, pp.55-75; Stouffer et al., Studies in Social Psychology II, pp.73-7.
} 
operations often compelled him to face those threats in an exhausted, sleep deprived and

psychologically vulnerable condition. How then does this situation compare to that faced by the Athenian hoplite?

\subsection{The Athenian Hoplite and his Environment}

Like the American soldier, the Athenian hoplite carried into battle with him a highly distinctive set of norms and values. Unlike those influenced by Christianity, however, these were profoundly pugnacious. The explanation for this, of course, lies in the peculiar geo-political structure of Classical Greece, where a thin veneer of cultural unity overlay an aggressive agglomeration of small, fiercely independent and mutually antagonistic poleis. ${ }^{67}$ In this singular environment, war, which the Greeks accepted as a legitimate tool of interstate relations, ${ }^{68}$ proliferated unconstrained by enforceable international laws ${ }^{69}$ or effective methods of conflict resolution. ${ }^{70}$ Consequently, since the

\footnotetext{
${ }^{67}$ See Hdt. VIII.144.2; Isoc. IV.43, 81; Plat. Rep. V.470c-d, with P. Low, Interstate Relations in Classical Greece: Morality and Power (Cambridge, 2007), pp.33-73; van Wees, Greek Warfare, pp.6-18. For extended discussion, see esp. E. Hall, Inventing the Barbarian: Greek Self-Definition through Tragedy (Oxford, 1989); B. Isaac, The Invention of Racism in Classical Antiquity (Oxford, 2004); cf. E. Gruen, Rethinking the Other in Antiquity (Princeton, 2011).

${ }^{68}$ Consider esp. Plat. Laws. I.625e-26a, with M. Finley, 'War and Empire' in M. Finley (ed.), Ancient History: Evidence and Models (London, 1985), pp.67-70; Low, Interstate Relations, p.108, n.111; van Wees, Greek Warfare, pp.3-5, pp.19-33, also K. Dover, Greek Popular Morality in the Time of Plato and Aristotle (Oxford, 1974), pp.160-1, pp.310-6; Y. Garlan, War in the Ancient World: A Social History (London, 1975), p.18; A. Momigliano, 'Some Observations on Causes of War in Ancient Historiography' in A. Momigliano (ed.), Studies in Historiography (London, 1966), pp.112-26; Tritle, From Melos to My Lai, pp.28-9; G. Zampaglione, The Idea of Peace in Antiquity (London, 1973), pp.1-18, pp.28-35, pp.60-4.

${ }^{69}$ D. Bederman, International Law in Antiquity (Cambridge, 2001), pp.154-5, p.174, p.177; Low, Interstate Relations, pp.77-128; L. Mitchell, 'Philia, Eunoia and Greek Interstate Relations', Antichthon, Vol.31 (1997), p.41, p.44; C. Phillipson, The International Law and Custom of Ancient Greece and Rome, Vol.II (London, 1911), p.28, p.30, p.32, p.43, p.58; G. Sheets, 'Conceptualising International Law in Thucydides', $A J P h$, Vol.115 (1994), p.54-6, p.62; cf. G. Herman, 'Treaties and Alliances in the World of Thucydides', PCPhS, Vol.36, (1990), p.84; H. Koh, 'Why Do Nations Obey International Law?', Yale Law Journal, Vol.106 (1997), p.2604.

${ }^{70}$ Although arbitration clauses often appeared in Greek treaties (see, for instance, Thuc. V.79.1, with M. Tod, International Arbitration Amongst the Greeks (Oxford, 1913), pp.174-5; Low, Interstate Relations, pp.105-8; C. Phillipson, The International Law and Custom of Ancient Greece and Rome, Vol.I (London, 1911), pp.129-130, p.138), in the absence of effective means of enforcement, they rarely achieved their aim (consider, for example, Thuc. I.78.4, 85.2, V.15.4, with S. Ager, 'Why War? Some Views on International
} 
sovereignty and survival of his polis was secured by the warrior, the Greeks held nonmartial aspects of manhood secondary to battlefield bravery, ${ }^{71}$ which they considered an unqualified social good that both defined a man and determined his social worth. ${ }^{72}$

Naturally, as Athenian society was profoundly performative, ${ }^{73}$ a warrior had to demonstrate rather than merely declare his bravery, ${ }^{74}$ either by dying on the battlefield, ${ }^{75}$ or by performing creditably in combat and earning the acclaim of those who witnessed his creditable conduct. ${ }^{76}$ Accordingly, for the Athenians, war was more than a means of

Arbitration in Ancient Greece', EMC, Vol.12 (1993), p.8, pp.10-11; Tod, International Arbitration, p.189, also F. Adcock and D. Mosley, Diplomacy in Ancient Greece (London, 1975), pp.230-2, p.239, p.244; Bederman, International Law in Antiquity, pp.164-5, p.177; Zampaglione, The Idea of Peace in Antiquity, p.18, pp.28-35).

${ }^{71}$ A. Adkins, Merit and Responsibility: A Study in Greek Values (London, 1960), p.73, pp.156-68, p.231, p.340; D. Cairns, Aidōs: The Psychology and Ethics of Honour and Shame in Ancient Greek Literature (Oxford, 1993), pp.147-77; Dover, Greek Popular Morality, p.67, p.161; J. Roisman, 'The Rhetoric of Courage in the Athenian Orators' in R. Rosen and I. Sluiter (eds.), Andreia: Studies in Manliness and Courage in Classical Antiquity (Boston, 2002), pp.127-8.

${ }^{72}$ For this argument in full, see Crowley, The Psychology of the Athenian Hoplite, pp.86-8, with Adkins, Merit and Responsibility, p.73, p.249; K. Bassi, 'The Semantics of Manliness in Ancient Greece' in R. Rosen and I. Sluiter (eds.), Andreia: Studies in Manliness and Courage in Classical Antiquity (Boston, 2002), pp.25-58; M. Christ, The Bad Citizen in Classical Athens (Cambridge, 2006), pp.47-8, pp.88-142; E. Cohen, 'The High Cost of Andreia at Athens' in R. Rosen and I. Sluiter (eds.), Andreia: Studies in Manliness and Courage in Classical Antiquity (Boston, 2002), pp.144-65; Dover, Greek Popular Morality, p.41, pp.161-7; D. Pritchard, 'The Fractured Imaginary: Popular Thinking on Military Matters in Fifth Century Athens', AH, Vol.28 (1998), pp.44-9; A. Rademaker, “Most Citizens are Europrôktoi Now": (Un)manliness in Aristophanes' in R. Rosen and I. Sluiter (eds.), Andreia: Studies in Manliness and Courage in Classical Antiquity (Boston, 2002), pp.115-25; Roisman, 'The Rhetoric of Courage', pp.12643, The Rhetoric of Manhood: Masculinity in the Attic Orators (London, 2005), pp.1-2, pp.7-8, p.67, pp.84101, pp.105-6, pp.188-92, pp.205-14; W. Runciman, 'Greek Hoplites, Warrior Culture, and Indirect Bias', The Journal of the Royal Anthropological Institute, Vol.4 (1998), pp.740-2; Zampaglione, The Idea of Peace in Antiquity, pp.60-4.

${ }^{73}$ Adkins, Merit and Responsibility, pp.153-6; Christ, The Bad Citizen, pp.10-12, pp.38-9, pp.112-8; Roisman, 'The Rhetoric of Courage', p.127, The Rhetoric of Manhood, pp.95-6.

${ }^{74}$ Xen. Symp. VIII.43; Lyc. I.104; Lys. XVIII.24, XXX.26; Xen. Hell. VII.1.21, 4.32.

75 Dem. LX.37; Lys. II.1-2; 67-70, 79-81; Thuc. II.42.2-3; P. Liddel, Civic Obligation and Individual Liberty in Ancient Athens (Oxford, 2007), p.288; Roisman, The Rhetoric of Manhood, pp.67-71, p.111, pp.205-14; S. Yoshitake, 'Aretē and the Achievements of the War Dead: The Logic of Praise in the Athenian Funeral Oration' in D. Pritchard (ed.), War, Democracy and Culture in Classical Athens (Cambridge, 2010), pp.359-77.

${ }^{76}$ Crowley, The Psychology of the Athenian Hoplite, pp.66-9, pp.86-8, with Christ, The Bad Citizen, p.12, pp.82-142; Adkins, Merit and Responsibility, pp.198-214; Bassi, 'The Semantics of Manliness', pp.55-6; Roisman, 'The Rhetoric of Courage', pp.126-43, The Rhetoric of Manhood, pp.109-11. 
defending or advancing the interests of Athens, it was a rite of passage which guarded the boundary between adolescence and manhood. ${ }^{77}$

Of course, although armed conflict was embedded in the Athenian kosmos, the Athenians were not blind to the allure of peace: they enjoyed both its benefits and its tranquillity, and they recognised that since war entailed destruction, loss and sorrow, it should be avoided where possible. Nevertheless, despite this recognition, it is striking that expressions of humanistic sentiment are not only relatively infrequent in Athenian discourse, but most were generated by the Peloponnesian War, and those that were not are completely overshadowed by the dominant orthodoxy which fully acknowledged the human cost of war but wholeheartedly embraced it nonetheless. ${ }^{78}$

Again, this is easy to explain. Athens was an interventionist imperial powerhouse which ruthlessly deployed the institution of war to compete for dominance in one of the harshest geo-political environments in history. ${ }^{79}$ Unsurprisingly, since it formed the foundation upon which Athenian greatness was built, the Athenians venerated war, ${ }^{80}$ and

\footnotetext{
77 Crowley, The Psychology of the Athenian Hoplite, pp.86-8, also Christ, The Bad Citizen, pp.112-8; Finley, 'War and Empire', p.68; Roisman, 'The Rhetoric of Courage', pp.127-9, The Rhetoric of Manhood, pp.163-85.

${ }_{78}$ Crowley, The Psychology of the Athenian Hoplite, pp.88-92, with P. Karavites, 'Greek Interstate Relations in the Fifth Century BC', PP, Vol.216 (1984), pp.162-5; Low, Interstate Relations, p.2, pp.16173; Garlan, War in the Ancient World, pp.15-16; Momigliano, 'Some Observations on the Causes of War', pp.113-23; Roisman, 'The Rhetoric of Courage', pp.132, The Rhetoric of Manhood, pp.113-7; Runciman, 'Greek Hoplites', pp.742-3; Zampaglione, The Idea of Peace in Antiquity, pp.71-106, also Section 3.1, n.70.

${ }^{79}$ Low, Interstate Relations, pp.177-211; J. Ober, Democracy and Knowledge: Innovation and Learning in Classical Athens (Oxford, 2008), pp.1-79; K. Raaflaub, 'The Transformation of Athens in the Fifth Century' in D. Boedeker and K. Raaflaub (eds.), Democracy, Empire and the Arts in Fifth-Century Athens (London, 1998), pp.15-41, also Section 3.1, ns.68-70.

${ }^{80}$ As, indeed, did the Greeks generally. Consider, for instance, Aristoph. Kn. 565-80; Hdt. I.1.0; Isoc. XII.250-9, XV.60-1, 119-20, 306-7; Paus. I.15.3-4; Plat. Lach. 182c, Laws. VIII.831e, Prot. 354a-b, 359e360a, Rep. X.599c-d; Thuc. II.64-2-6, VI.41.3, VII.56.2, 59.2, 66.1, 70.6-8, 71.1, 86.2-3, VIII.2.1-2, XII.950e-51a; Xen. Anab. VII.6.31-3, Cav. VIII.7, Ec. IV.4, Hell. IV.5.6, V.1.17, VI.5.23, Hiero. II.15-16, Mem. IV.6.13-14, with Crowley, The Psychology of the Athenian Hoplite, pp.88-92; T. Hölscher, 'Images and Political Identity: The Case of Athens', in D. Boedeker and K. Raaflaub (eds.), Democracy, Empire, and the Arts in Fifth-Century Athens (London, 1998), pp.153-83; F. Lissarrague, 'The World of the Warrior' in C. Bérard et al. (eds), A City of Images: Iconography and Society in Ancient Greece (Guildford,
} 
not just as an abstract concept, but also as a tangible human experience reduced to its three most basic components: fighting, killing and dying, a triumvirate which together forms the most brutal distillation of war: combat.

For the Athenians, the ability to fight in close combat was the highest and most glorious expression of the masculine ideal. ${ }^{81}$ Similarly, the desired end result of that engagement, the death of the opponent, was also something eagerly embraced. Such hardheartedness stems, in no small part, from a principle central to Athenian culture, namely that of helping friends and harming enemies, a doctrine not only deeply internalised by Athenian men, but also one they felt obliged to obey. ${ }^{82}$ This exerted such normative force that Athenian men felt compelled to respond violently to their enemies, even if they were fellow citizens, with whom they were ideally expected to collaborate. ${ }^{83}$ Naturally, external enemies invited not collaboration but elimination, and so on the

1989), pp.39-51; Pritchard, 'The Fractured Imaginary', pp.48-9; K. Raaflaub, 'Father of All, Destroyer of All: War in Late Fifth-Century Athenian Discourse and Ideology' in D. McCann and B. Strauss (eds.), War and Democracy: A Comparative Study of the Korean War and the Peloponnesian War (London, 2001), pp.307-56, 'The Transformation of Athens', p.18, p.39; Rademaker, "Most Citizens are Europrôktoi Now", pp.115-25; Roisman, 'The Rhetoric of Courage', pp.132-6, The Rhetoric of Manhood, pp.113-7, pp.134-5; Runciman, 'Greek Hoplites', pp.731-51; Zampaglione, The Idea of Peace in Antiquity, pp.71-82.

${ }_{81}$ Aristoph. Wasps 1114-21; Plat. Laws I.641b, Rep. II.375a-d; Soph. Ant. 640-681; cf. Plat. Laws VIII.828d-829a; Plut. Pel. XVII.6, with further evidence and discussion in Crowley, The Psychology of the Athenian Hoplite, pp.86-88, pp.92-6.

${ }^{82}$ Aesch. Eum. 465-7, 745-54, Lib. 264-300, 1024-31; Aristoph. Birds. 420-1; Dem. XVIII.280, 292; Eur. Ba. 878-80, El. 807, Ion. 1045-7; Or. 665-70, Med. 807-10; Isoc. XV.99; Lys. I.15-17, 44-5, VII.40-1, IX.20, XXXII.22, II.8; Plat. Men. 71e, Rep. I.331e-34b, II.375a-d; Plut. Arist. X.8; Soph. Ant. 643-4, Oed. Col. 27-272; Xen. Anab. I.3.6, 9.11, VII.7.46, Cyrop. I.4.25, 5.13, Ec. IV.2-3, Hiero. II.2, Mem. I.6.9, II.1.3, 19, 6.35, V.5.10, with Dover, Greek Popular Morality, pp.180-4; Roisman, The Rhetoric of Manhood, pp.59-63, also Low, Interstate Relations, pp.38-43.

${ }^{83}$ Dem. LIV.13-14, 18-19, 34-6, 42, XXI.2, 20, 28, 40, 74, 76, 120, 141; cf. Andoc. I.56; Plat. Rep. VIII.560d-e, with N. Fisher, 'Violence, Masculinity and the Law in Classical Athens' in L. Foxhall and J. Salmon (eds.), When Men Were Men: Masculinity, Power and Identity in Classical Antiquity (London, 1998), pp.68-97; Liddel, Civic Obligation, p.155; Roisman, 'The Rhetoric of Courage', pp.136-41, The Rhetoric of Manhood, pp.71-9, pp.170-3; cf. Herman, Morality and Behaviour in Democratic Athens, esp. pp.410-14. 
battlefield, lethal violence was not only morally unambiguous, it was also utterly unconstrained. ${ }^{84}$

The Athenians, however, did not only kill their enemies, they were also killed by them, and so many men would have witnessed the deaths of their comrades at close hand on more than one occasion. ${ }^{85}$ Yet, whilst such losses were lamented, ${ }^{86}$ the Athenians nevertheless chose to construe death in combat not as a premature end, but as a timely culmination. ${ }^{87}$ Accordingly, at Athens, the war dead enjoyed a special social significance. Having demonstrated their unimpeachable courage they reflected undying glory on both state and surviving family, ${ }^{88}$ and in return for their sacrifice, they escaped mortality, and as something close to heroes, they were immortalised by inscriptions, and annually honoured by the spectacular state funeral Athens held for her fallen. ${ }^{89}$ Thus, for the Athenians, death, far from dimming the bright glory of combat, was instead its most glorious aspect.

\footnotetext{
${ }^{84}$ See above, Section 3.1, n. 82 .

${ }^{85}$ For instance, in Aetolia in 426 BC (Thuc. III.94.1-98.5), Delion in 424 BC (Thuc. IV.89.1-101.2) and of course, on Sicily, in 413 BC (Thuc. VII.83.1-85.4). Given that the Military Participation Ratio (for which see S. Andreski, Military Organization and Society (London, 1968)) was so high at Athens, such experiences would have been particularly widespread.

${ }^{86}$ Dem. LX.37; Lys. II.71; Thuc. II.34.4, 44.1-46.2.

${ }^{87}$ Aeschin. III.154; Dem. XVIII.205, L.63; Isoc. VIII.39; Lys. II.79, XXI.24, 27, XXXI.5-7; Plat. Laws IX.874e-875c; Thuc. II.41.5-42.4. For this idea generally, see Aristot. Nic. Eth. 1116b; Dem. LX.37; Eur. Tro. 400-2; Is. VI.9; Lyc. I.47-8; Lys. II. 79-81; XVIII.26; Tyrt. XII.21-6; Xen. Anab. VI.3.17-19, Hell. I.6.32, II.4.17, IV.4.6-7, with additional discussion in Bassi, 'The Semantics of Manliness', pp.55-6; Cairns, Aidōs, pp.147-77; Karavites, 'Greek Interstate Relations', pp.162-5; Liddel, Civic Obligation, p.288; Lissarrague, 'The World of the Warrior', pp.49-51; Roisman, 'The Rhetoric of Courage', pp.128-9, The Rhetoric of Manhood, pp.67-71, p.111, pp.205-14; Zampaglione, The Idea of Peace in Antiquity, pp.64-71.

${ }^{88}$ Hdt. I.30.3-5; Dem. LX.37; Eur. Tro. 400-2; Lyc. I.47-8; Thuc. II.41.4-43.4, with Section 3.1, n.87.

${ }^{89}$ See esp. Thuc. II.34.1-46.2; $I G \mathrm{I}^{3} 1162$, also Lys. II.80, with D. Bradeen, 'Athenian Casualty Lists', Hesperia, Vol.33 (1964), pp.16-62, 'The Athenian Casualty Lists', CQ, Vol.19 (1969), pp.145-59; F. Jacoby, 'Patrios Nomos: State Burial in Athens and the Public Cemetery in the Kerameikos', JHS, Vol.64 (1944), pp.37-66; N. Loraux, The Invention of Athens: The Funeral Oration in the Classical City (London, 1986), esp. pp.15-131.
} 
These bellicose views also received religious amplification. Admittedly, Ares, who personified the more sinister aspects of war, appears to have revolted the Greeks. ${ }^{90}$ Furthermore, religious sentiments, by underpinning the respect normally accorded to temples, truces, heralds, holy days and enemy dead, undoubtedly offered a welcome degree of amelioration. ${ }^{91}$ Nevertheless, there is no hint of pacifism in Greek religion, and the gods with whom men communed, usually through the medium of animal sacrifice, during which, tellingly, the victim had its throat cut with an edged weapon, ${ }^{92}$ were often warriors themselves, and as such, they both approved of the institution of war $^{93}$ and accepted its utility in interstate relations. ${ }^{94}$ As a result, for the Greek warrior, the gods were a potential source of support, and if their favour could be obtained by means of offerings and promises, ${ }^{95}$ they could be induced to work for him and against his enemies. ${ }^{96}$

\footnotetext{
${ }^{90}$ N. Fisher, Hybris: A Study in the Values of Honour and Shame in Ancient Greece (Warminster, 1992), pp.504-5, also S. Deacy, 'Athena and Ares: War, Violence and Warlike Deities' in H. van Wees (ed.), War and Violence in Ancient Greece (London, 2000), pp.285-298; Zampaglione, The Idea of Peace, pp.18-23.

${ }^{91}$ Garlan, War in the Ancient World, pp.23-77; M. Goodman and A. Holladay, 'Religious Scruples in Ancient Warfare', $C Q$, Vol.36 (1986), pp.151-71; P. Krentz, 'Fighting by the Rules: The Invention of the Hoplite Agōn', Hesperia, Vol.71 (2002), pp.23-39; Low, Interstate Relations, pp.96-7, p.126; J. Ober, 'The Rules of War in Classical Greece' in J. Ober (ed.), The Athenian Revolution: Essays on Ancient Greek Democracy and Political Theory (Princeton, 1996), pp.53-71; cf. Thuc. IV.97.2-3; Xen. Hell. III.5.23-4.

${ }^{92}$ Hom. Od. III.430-63; Eur. El. 774-843, with W. Burkett, Homo Necans: The Anthropology of Ancient Greek Sacrificial Ritual and Myth (London, 1983), pp.1-12, pp.293-7.

${ }^{93}$ Ant. IV.1.2; Lyc. I.99-101; Plut. Nic. XVIII.1; Thuc. III.56.2, with Burkett, Homo Necans, pp.35-48; W. Connor, 'Early Greek Land Warfare as Symbolic Expression', $P \& P$, Vol.119 (1988), pp.18-29; Dover, Greek Popular Morality, pp.255-7.

${ }^{94}$ Dem. IV.45; On. Strat. X.25-7; Plat. Laws I.631c-d, VII.803e, VII.823c-24c; Thuc. I.123.1-2; Xen. Anab. I.4.18, III.1.19-23, 2.9-13, V.2.9-11, VI.3.17-18, Cyrop. VII.1.10-15, 20, Hell. III.4.18, VII.1.4-5, 8-11, with Goodman and Holladay, 'Religious Scruples in Ancient Warfare', p.151; Lissarrague, 'The World of the Warrior', pp.39-51; Roisman, 'The Rhetoric of Courage', p.132.

${ }^{95}$ Aristoph. Kn. 841-59; Diod. Sic. XV.85.1, XVI.22; Hdt. VI.76.1-2, VIII.64.1, IX.61.2-62.1; Isoc. VII.10; Lys. X.27-8; Paus. IX.13.4; Plat. Laws VII.803c-e, Rep. V.469e-470a; Plut. Arist. IX.1-2, X.3-5, XVII.6XVIII.3-5, XIX.6, XX.4, XXI.1, Per. XVII.1-2, Them. VIII.2-3, XIII.2-3, XV.2; Thuc. I.32.2, 118.3, VI.30.1-32.2, 69.2, VII.69.2; Xen. Anab. III.2.9-13, IV.3.17-19, V.2.9-11, 22, VI.4.12-25, Cyrop. VII.1.35, Ec. V.19-20, Hell. I.6.11, III.5.7, IV.2.20, 3.21, 7.2, 7, VII.2.20-1, with Goodman and Holladay, 'Religious Scruples', p.152; A. Jackson, 'Hoplites and the Gods: The Dedication of Captured Arms and Armour' in V. Hanson (ed.), Hoplites: The Classical Greek Battle Experience (London, 1991), pp.228-49; M. Jameson, 'Sacrifice Before Battle' in V. Hanson (ed.), Hoplites: The Classical Greek Battle Experience (London, 1991), pp.197-227; R. Parker, 'Sacrifice and Battle' in H. van Wees (ed.), War and Violence in Ancient
} 
This ensured that the Greek warrior's relationship with his gods was both profound and pitiless, as two particularly grim examples offered by Xenophon demonstrate. In the first, he recounts how the Athenians promised to sacrifice a goat to Artemis for every Persian they killed at Marathon. The goddess, however, was so generous that the slaughter of Persians outstripped the supply of animals, and although the Athenians subsequently sacrificed by annual instalments of five hundred goats, their blood-debt was so great that, according to Xenophon, it was still being paid nearly a hundred years after it had been incurred. ${ }^{97}$ In the second, even more dreadful example, Xenophon describes an awful Spartan massacre of corralled and utterly helpless enemies, which, in his view, was not only something that a Greek warrior might legitimately pray for, but its successful execution, in this instance, signified by 'heaps of corpses', could actually be considered a 'gift of heaven' ${ }^{98}$

Although shocking to a modern reader, Xenophon's ruthless religious Weltanschuung is entirely understandable. His formative years had been spent in the shadow of his city's patron, Athena, the warrior goddess par excellence. Her citizens paraded their military power in her honour during her festival, the Panathenaea. ${ }^{99}$ They

Greece (London, 2000), pp.299-314; W. Pritchett, The Greek State at War: Part III (Berkeley, 1979), pp.296-321; Runciman, 'Greek Hoplites', pp.738-40.

${ }^{96}$ Dem. XVIII.324; Thuc. I.118.3, also Hdt. VIII.64.1-2; Thuc. I.86.5, 123.1-2; Xen. Anab. III.2.10, IV.3.815, V.2.24, Cyrop. VII.1.11, Ec. V.19-20, Hell. IV.4.2-3, 12, VI.4.7-8, VII.2.21, 5.9-10, 13, 26, Mem. II.1.32-3; Lissarrague, 'The World of the Warrior', p.42.

${ }^{97}$ Xen. Anab. III.2.10-14; cf. Hdt. VI.117.1. For similar examples, see Xen. Anab. III.2.9, IV.8.25 and Diod. Sic. XIII.102.2.

${ }^{98}$ Xen. Hell. IV.4.12 (trans. C. Brownson); cf. § VII.1.32-2, with Cyrop. VII.1.11-13, also Thuc. I.106.1-2.

${ }^{99}$ W. Connor, 'Tribes, Festivals and Processions: Civic Ceremonial and Political Manipulation in Archaic Greece', JHS, Vol.107 (1987), pp.48-9, also W. Connor, 'Festivals and Athenian Democracy' in M. Sakellariou (ed.), Colloque International: Démocratie Athénienne et Culture (Athens, 1996), pp.79-90; L. Maurizio, 'The Panathenaic Procession: Athens' Participatory Democracy on Display?' in D. Boedeker and K. Raaflaub (eds.), Democracy, Empire and the Arts in Fifth-Century Athens (London, 1998), pp.297-317; J. Neils, 'The Panathenaia and Kleisthenic Ideology' in W. Coulson, O. Palagia, T. Shear, H. Shapiro and F. Frost (eds.), The Archaeology of Athens and Attica under the Democracy (Oxford, 1994), pp.151-60. For similar manifestations of militarism in the Great Dionysia, see W. Connor, 'Civil Society, Dionysiac 
depicted her, in Athenian art, as the personification of Athenian martial virtue, ${ }^{100}$ standing both with and for the Athenian hoplite, not only fighting at his side, but also celebrating his victories and grieving for his losses. ${ }^{101}$ Most revealingly, they portrayed her, in the warrior departure scenes often found on Attic pots, displacing the hoplite's wife or mother in order to assist him while he armed himself for battle against those hostile to her polis. ${ }^{102}$

Certainly, then, the norms and values the Athenian hoplite carried with him into battle were strikingly different to those of the American infantryman, and so too was the social environment in which he fought. As a convergence of evidence demonstrates, the Athenian hoplite mobilised, deployed and fought alongside his fellow demesmen. ${ }^{103}$ This is significant because the deme, the smallest subdivision of the Athenian body-politic,

Festival and the Athenian Democracy' in J. Ober and C. Hedrick (eds.), Demokratia: A Conversation on Democracies Ancient and Modern (Princeton, 1996), pp.217-26, 'Festivals and Athenian Democracy', pp.79-90; S. Goldhill, 'The Great Dionysia and Civic Ideology' in J. Winkler and F. Zeitlin (eds.), Nothing to Do With Dionysos?: Athenian Drama in its Social Context (Princeton, 1990), pp.97-129.

${ }^{100}$ Consider esp. Plat. Laws VII.796b-c, also Deacy, 'Athena and Ares', pp.285-98; Finley, 'War and Empire', pp.68-70; Hölscher, 'Images and Political Identity', pp.153-83; Raaflaub, 'Father of All, Destroyer of All', p.326, 'The Transformation of Athens', pp.15-41; Zampaglione, The Idea of Peace in Antiquity, pp.23-6.

${ }^{101}$ Hdt. V.77.4; Paus. I.15.3-4, with Hölscher, 'Images and Political Identity', pp.173-6; A. Villing, The Iconography of Athena in Attic Vase-painting from 440 BC-370 BC (Oxford MPhil, 1992), pp.32-3, esp. n.73.

102 See esp. Lissarrague, 'The World of the Warrior', pp.42-8, also J. Boardman, Athenian Red Figure Vases: The Classical Period (London, 1989), p.220; E. Holmberg, The Red-line Painter and the Workshop of the Acheloos Painter (Jonsered, 1990), pp.85-103; S. Matheson, Polygnotos and Vase Painting in Classical Athens (London, 1995), pp.269-76, 'A Farewell with Arms: Departing Warriors on Athenian Vases' in J. Barringer and J. Hurwit (eds.), Periklean Athens and its Legacy: Problems and Perspectives (Austin, 2005), pp.23-35; E. Pemberton, 'The Name Vase of the Peleus Painter', The Journal of the Walters Art Gallery, Vol.36 (1977), pp.62-72.

${ }^{103}$ For the evidence itself, see esp. Lys. XVI.14, XX.23; B. Petrakos, 'Anaskaphē Rhamnoūntos', Praktika tes en Athenais Archaiologikes Hetaireias, Vol.59 (1984), pp.197-8 (which discusses a collective military dedication made by the demesmen of Rhamnous), and for admittedly later corroboration, see Is. II.42; Thphr. Char. XXV.3. For the argument in full, see Crowley, The Psychology of the Athenian Hoplite, pp.46-9, with similar views expressed in N. Jones, The Associations of Classical Athens: The Response to Democracy (Oxford, 1999), p.58; R. Osborne, Demos: The Discovery of Classical Attika (London, 1985), p.82; N. Sekunda, 'Athenian Demography and Military Strength 338 - 322 BC', ABSA, Vol.87 (1992), pp.311-55; D. Whitehead, The Demes of Attica 508/7 - ca. 250 BC: A Political and Social Study (Princeton, 1986), pp.225-7; W. Wyse, The Speeches of Isaeus (Cambridge, 1904), p.268. 
was also by far the most socially cohesive. ${ }^{104}$ Most were small, rather internally-focused face-to-face communities of whose members were religiously, economically, politically and socially integrated. ${ }^{105}$ As a consequence, affiliation amongst demesmen was so profound and normative ${ }^{106}$ that any damage to this affiliative relationship was, for the unfortunate demesmen concerned, not merely transgressive, it was actually shameful. ${ }^{107}$

The tactical environment in which these men fought was also very different. The Athenian hoplite was a heavy infantryman who sacrificed speed and agility in order to maximise his capacity for close-quarters combat. To protect himself from troops, such as cavalry and light infantry, whose capacity for tactical mobility surpassed his own, he fought in a phalanx, a close-order formation predicated on mutual protection and tactical interdependency. ${ }^{108}$ Insofar as its table of organisation can be reconstructed, the Athenian phalanx seems to have been subdivided by ten medium-sized subunits, called taxeis, with each taxis in turn subdivided by an unknown number of smaller units called lochoi ${ }^{109}$ As the evidence suggests, demesmen were assigned to the same lochos, and deployed in tactically distinct files of men, usually eight deep, laterally arranged to produce eight

\footnotetext{
${ }^{104}$ Lys. XVI.14, XX.13, 23, XXIII.2-3, XXXI.15; Thuc. II.16.1-2, with Whitehead, The Demes of Attica, also A. Andrewes, The Greeks (London, 1967), p.84; Jones, The Associations of Classical Athens, p.122, p.171, p.297; Osborne, Demos, pp.88-104.

${ }^{105}$ See esp. Whitehead, The Demes of Attica, with additional discussion in Crowley, The Psychology of the Athenian Hoplite, pp.43-6.

106 Aristoph. Clouds 210-11, 1321-4, Eccl. 1023-4, 1114-9, Kn. 319-20, Peace 79, Wealth 253, 322; Aristot. Ath. Pol. XXI.4, XLII.1-2; Lys. VI.53, XXVII.12.

107 Aristoph. Clouds 1215-20; Is. fr. IV; Lys. XX.13; Whitehead, The Demes of Attica, pp.228-31, p.234, p.338; cf. Dem. LVII.63-5; Is. I.39, II.37.

${ }_{108}$ Aristot. Pol. IV.1297b; Dem. III.17; Eur. Her. 190-4; Plut. Arist. XVIII.3, Mor. 220a; Thuc. I.63.1-3, III.108.1-3, IV.126.1-6, V.66.1-4, 69.1, 71.1; Tyrt. X-XI; Xen. Hell. IV.2.18-19, V.1.12, VII.5.22; Mem. III.1.7, with Section 1.2, n.21.

${ }^{109}$ Taxeis: Aristot. Ath. Pol. XLI.3; Hdt. VI.111.1; Lys. XIII.79, XVI.15; Plut. Arist. V.1-5, Cim. XVII.3-5; Thuc. II.79.4-5, VI.98.4, 101.5, VIII.92.4. Lochoi: Aristoph. Ach. 575, 1073-4, Lys. 452-4; Aristot. Ath. Pol. LXI.3; Plut. Arist. XIV.2-3; Xen. Hell. I.2.3, Mem. III.1.5, 4.1; cf. Isoc. XV.116; Plut. Mor. 186f; Thuc. V.66.2-4; Xen. Lac. Pol. XI.4.
} 
serried ranks. Consequently, when the Athenian hoplite met his enemy, he did so surrounded by and in close order with his comrades. ${ }^{110}$

The technological environment in which the Athenian hoplite fought, which was largely determined by muscle-powered weapons, was also highly distinctive. ${ }^{111}$ As he discharged his main tactical duty, to close with and kill enemy hoplites, the principal threat the Athenian hoplite faced was from the stabbing spears and slashing swords of similarly armed and equipped opponents. ${ }^{112}$ Moreover, since he was normally protected by friendly cavalry and light infantry during deployment, the advance to contact and whilst in contact with the enemy, if he was victorious, the weapons wielded by enemy hoplites were the only threat he would face on the battlefield. ${ }^{113}$ However, if he was ineffectively screened by supporting arms, or if that protective screen was dispersed or his own phalanx atomised by defeat, he might find himself exposed to the javelins thrown by enemy cavalry and light infantry, as well as the sling stones and arrows of enemy slingers and archers. ${ }^{114}$

In comparison to the modern infantryman, then, the range of threats faced by the Athenian hoplite was relatively restricted, and so too was the logistical and technological

\footnotetext{
${ }^{110}$ See above, Section 3.1, n.103.

${ }^{111}$ For an experimental assessment of the power generated by the hoplite's weapons, see R. Gabriel and K. Metz, From Sumer to Rome: The Military Capabilities of Ancient Armies (Westport, Connecticut, 1991), pp.51-6, with additional discussion in E. Jarva, Archaiologia on Archaic Greek Body Armour (Rovaniemi, 1995), pp.139-44; Schwartz, Reinstating the Hoplite, pp.79-95; A. Snodgrass, Arms and Armour of the Greeks (London, 1967), p.56.

${ }^{112}$ For the mechanics of close-quarters battle, see V. Hanson, 'Hoplite Technology in Phalanx Battle' in V. Hanson (ed.), Hoplites: The Classical Greek Battle Experience (London, 1991), pp.63-84, and in the same volume, J. Lazenby, 'The Killing Zone', pp.87-109.

${ }^{113}$ For the tactical role of cavalry and light infantry, see F. Adcock, The Greek and Macedonian Art of War (London, 1964), pp.14-28, pp.47-53; van Wees, Greek Warfare, pp.61-71; E. Wheeler, 'Land Battles' in P. Sabin, H. van Wees and M. Whitby (eds.), The Cambridge History of Greek and Roman Warfare, Volume I (Cambridge, 2007), pp.186-223, with detailed additional discussion in J. Best, Thracian Peltasts and their Influence on Greek Warfare (Groningen, 1969) and L. Worley, Hippeis: The Cavalry of Ancient Greece (Oxford, 1994).

${ }^{114}$ See above, Section 3.1, n.113. This explains why most hoplites were killed during the pursuit, for which see Thuc. VI.69.1-3; Plat. Lach. 181a-b, 189b, Laws XII.961e-962a, Symp. 221a-c; Plut. Alc. VII.3.
} 
support he received. Typically, he mobilised with only a few days self-supplied rations, ${ }^{115}$ and after they were consumed, he was forced to live by purchasing food from nearby markets when in neutral or friendly territory, and by plunder when in that of the enemy. ${ }^{116}$ Accordingly, since he could live by plunder only when enemy crops were ripe, extended operations in enemy territory, such as those conducted by the Athenians on Sicily, were difficult to sustain. In addition, without the technological aids required for the amplification of ambient light, night operations, like the disastrous Athenian attack on Epipolae, were extremely risky, and therefore also comparatively rare. ${ }^{117}$

\subsection{The Athenian Hoplite's Susceptibility to PTSD/CSI}

It seems obvious, therefore, that the Athenian hoplite entered combat with a historically-specific set of norms and values, and that he operated in a historicallyspecific social, tactical and technological environment. What is not obvious, however, is that his pre-battle socialisation and every aspect of his environment combined to produce a historically-specific resistance to PTSD/combat stress injury.

Clearly, the religiously amplified and militarised norms and values internalised by the Athenian hoplite were stunningly congruent with his tactical role, which was to close with and kill his enemy. Consequently, he did not require re-socialisation prior to active service since he was, from childhood, continually conditioned for combat. ${ }^{118}$ Thus, instead of regretting the killing of his enemies, the Athenian hoplite gloried in their

\footnotetext{
${ }^{115}$ Aristoph. Ach. 197, 1073-1142, Peace 311-2, 1181-2, Wasps 243; cf. Thuc. I.48.1.

116 Thuc. II.101.5, IV.6.1; VI.44.1-4, 50.1-2, VIII.95.4, with Anderson, Military Theory, pp.43-66; W. Pritchett, The Greek State at War, Part I (Berkeley, 1971), pp.30-52; van Wees, Greek Warfare, pp.102-8.

${ }^{117}$ See above, Section 3.1, n.116, also L. Foxhall, 'Farming and Fighting in Ancient Greece' in J. Rich and G. Shipley (eds.), War and Society in the Greek World (London, 1995), pp.134-45. For the operations conducted during the Sicilian Campaign, see Thuc. VI.64.1-72.5, 96.1-97.5, 100.1-3, VII.5.1-4, 6.1-4, 43.1$45.2,75.1-86.5$, and for the difficulty and danger inherent to operations at night, see esp. Thuc. VII.44.245.2 .

${ }^{118}$ See above, Section 3.1, ns.81-102.
} 
deaths. Xenophon, for instance, describes how, at the point when an enemy formation breaks and close-quarters combat gives way to the slaughter of fleeing and panic-stricken men, the emotion typically experienced by pursuing hoplites was unbridled joy. Furthermore, he adds, the pride men take in their own personal tally of kills tempts so many to exaggerate that their boastful claims exceed the actual body count. ${ }^{119}$ The same feelings are also unambiguously expressed in a famous epitaph, to Pythion of Megara. That claims Pythion was a good man because of his capacity to help his friends and harm his enemies, which he apparently demonstrated by helping to save three Athenian taxeis, which had been cut off near his homeland, probably in $446 \mathrm{BC}$, and by personally killing seven men in close-quarters combat. As Dover perceptively observes, the fact that, according to the inscription, Pythion then entered the underworld 'having brought sorrow to no one among all the men who dwell on the earth ${ }^{120}$ demonstrates that the sorrow of enemies was not merely inconsequential, it was actually beyond reflective consideration. ${ }^{121}$

The successful performance of his battlefield role, therefore, was not psychologically toxic to the Athenian hoplite, nor was he forced to perform it without the full support his social environment. On the contrary, he mobilised, deployed and fought together with his fellow demesmen, and so, unlike the American infantryman, whose military service entailed the ongoing disruption of his social environment, the Athenian hoplite met his enemy surrounded by the men of own cohesive community whose

\footnotetext{
${ }^{119}$ Xen. Hiero II.15-16.

${ }^{120} I G \mathrm{I}^{3}$ 1353/ML 51/Fornara 101/Tod 41 (trans. K. Dover); cf. Diod. Sic. XII.5-7; Plut. Per. XXII.1-3; Thuc. I.114.1-115.1.

${ }^{121}$ Dover, Greek Popular Morality, pp.280-2, with additional discussion in Crowley, The Psychology of the Athenian Hoplite, pp.92-6. For further corroboration, see esp. Xen. Anab. IV.1.22-6, Hell. IV.4.12, with M. Anderson, 'Socrates as Hoplite', AncPhil. Vol.25 (2005), pp.273-89; Fisher, Hybris, pp.510-11; P. Green, 'War and Morality in Fifth-Century Athens: The Case of Euripides' Trojan Women', AHB, Vol.13 (1999), pp.97-110.
} 
protective affiliation both shielded him from the corrosive effects of apprehension and enhanced his psychological resilience. ${ }^{122}$

This psychological resilience was further reinforced by the Athenian hoplite's tactical environment, which virtually ensured the close physical proximity that combatants crave. Unlike the American infantryman, who sought safety in dispersion and often met his enemy isolated from his peers, the Athenian hoplite sought salvation in close order, and consequently, when he met his enemy, he was able to do so whilst deriving the maximum comfort from the close physical proximity of his surrounding comrades. ${ }^{123}$

Finally, the Athenian hoplite's psychological resilience was further enhanced by the technological environment in which he operated. Two aspects of this environment are especially notable. The first is that during conventional operations, the main threats he faced, that is those presented by other warriors armed with muscled-powered weapons, could be countered by the most psychologically benign Lazarus response, namely direct action. Specifically, during main force encounters, the Athenian hoplite could eliminate the threat he faced from enemy hoplites by closing with and killing them or, if overmatched, he could break contact under the cover of friendly cavalry and light infantry. ${ }^{124}$ Indeed, even during a tactical worst case scenario, in which his own phalanx was atomised and relentlessly pursued by more tactically mobile troops, the only option

\footnotetext{
${ }^{122}$ See above, Section 3.1, ns.103-10; cf. Section 2.1, ns.28-36, Section 2.2, ns.51-6.

${ }^{123}$ See above, Section 3.1, ns.108-10; cf. Section 2.1, ns.37-8, Section 2.2, ns.57-60.

${ }^{124}$ See above, Section 1.2, n.21, also Section 3.1, ns.112-13.
} 
available to the hoplite, uncontrolled flight, usually facilitated by the abandonment of the shield, was itself a form of direct action. ${ }^{125}$

The second notable aspect of the technological environment is the limited duration in which the Athenian hoplite had to cope with the stresses and strains of the ancient battlefield. Main force encounters were mercifully brief, and in the absence of sophisticated logistical support, the Athenian hoplite was not typically expected to conduct extended operations, nor was he, without the ability to amplify ambient light, usually required to fight during the hours of darkness. ${ }^{126}$ Admittedly, because the Greeks generally lacked the technology for breach and the will to storm, siege operations, normally conducted by circumvallation, did entail continuous contact with the enemy and, in consequence, such operations undoubtedly required a psychologically toxic Lazarus response, namely palliation. ${ }^{127}$ Nevertheless, during conventional operations the Athenian hoplite was largely protected against progressive exhaustion and sleep deprivation, and all the subsequent psychological vulnerabilities entailed thereby. ${ }^{128}$

The Athenian hoplite, therefore, was profoundly protected against PTSD/CSI as a result of a convergence of historically-specific factors. Firstly, the martial norms and values he took to the battlefield ensured that the successful performance of his battlefield role was not psychologically harmful. Secondly, his social environment allowed him to receive all the benefits that protective affiliation could provide. Thirdly, his tactical

\footnotetext{
${ }^{125}$ For the pursuit, see Section 3.1, n.114, and for abandonment of the shield in the course thereof, see Aristoph. Ach. 1129, Kn. 367, 389-94, Thes. 812-24, 830-45; Lys. X.8-9, 12, 21, 22-4, 27-30, XIV.4-8, 10, XVI.15, XXI.20; Xen. Symp. II.8-19.

${ }^{126}$ See above, Section 3.1, ns.115-17, with the comparative brevity of combat discussed in Schwartz, Reinstating the Hoplite, pp.201-22.

${ }^{127}$ Consider, for example, the siege of Plataea, $429-27$ BC (Thuc. II.71-8, III.20-4, 51-68) and that of Syracuse, 415 - 13 BC (Thuc. VI.52-104, VII.1-85). For siege warfare generally, see B. Strauss, 'Naval Battles and Sieges' in P. Sabin, H. van Wees, and M. Whitby (eds.), The Cambridge History of Greek and Roman Warfare, Volume I. (Cambridge, 2007), pp.237-47; van Wees, Greek Warfare, pp.138-50.

${ }^{128}$ See above, Section 3.1, ns.115-17, Section, 3.2, n.126.
} 
environment almost guaranteed him all the comfort he could derive from the physical proximity of his peers. Fourthly, his technological environment enabled him to confront the threats he faced during conventional operations with the most psychologically benign response, and to face those threats with his psychological resilience largely unaffected by the insidious effects of exhaustion or sleep deprivation.

\section{Conclusion}

The American infantryman and the Athenian hoplite both performed the same tactical role, and this sometimes tempts even the most impressive modern scholars to read evidence in way that equates their experiences. Nevertheless, despite the tactical similarity of these combatants, it is clear that the norms and values they carried into combat, and the social, tactical and technological environments in which they fought, were both historically-specific and radically divergent. Furthermore, it would appear that these historically-specific and radically divergent circumstances left the American infantryman critically vulnerable to PTSD/CSI whilst the Athenian hoplite was effectively immunised against the same risk. In Popperian terms, then, the Athenian hoplite is a black swan. Consequently, no matter how many white swans are marshalled in support of the universalist position, it seems that Donovan and his academic admirers are mistaken: the soldier is not, and indeed, can never be, universal. 


\section{Bibliography}

Adcock, F.

The Greek and Macedonian Art of War (London, 1964).

Adcock, F.

Diplomacy in Ancient Greece (London, 1975).

\& Mosley, D.

Adkins, A.

Merit and Responsibility: A Study in Greek Values (London, 1960).

Adler, A. et al. 'A2 Diagnostic Criterion for Combat-Related Posttraumatic Stress Disorder', Journal of Traumatic Stress, Vol.21 (2008), pp.301-8.

Ager, S.

'Why War? Some Views on International Arbitration in Ancient Greece', EMC, Vol.12 (1993), pp.1-13.

Aldwin, C.

Stress, Coping, and Development: An Integrative Perspective (New York, 1994).

Anderson, J. Military Theory and Practice in the Age of Xenophon (London, 1970).

Anderson, M. $\quad$ 'Socrates as Hoplite', AncPhil, Vol.25 (2005), pp.273-89.

Andreski, S. $\quad$ Military Organization and Society (London, 1968).

Andrewes, A. The Greeks (London, 1967).

Anon. $\quad$ The Volunteer's Pocket Book (Beverley, 1991).

APA Diagnostic and Statistical Manual of Mental Disorders (Washington, 1994).

Baron, R. Social Psychology (New Delhi, 2004).

\& Byrne, D.

Bassi, K.

'The Semantics of Manliness in Ancient Greece' in R. Rosen and I. Sluiter (eds.), Andreia: Studies in Manliness and Courage in Classical Antiquity (Boston, 2002), pp.25-58.

Beaumont, R.

'Combat Effectiveness: Paradigms and Paradoxes' in S. Sarkesian

\& Snyder, W.

(ed.), Combat Effectiveness: Cohesion, Stress, and the Volunteer Military (London, 1980), pp.20-56.

Bederman, D. International Law in Antiquity (Cambridge, 2001). 
Best, J.

Bidwell, S.

Boardman, J.

Bourke, J.

Bradeen, D.

Bradeen, D.

Bramley, V.

Bransby, G.

Burkett, W.

Buskist, W.,

Carlson, N.

\& Martin, G.

Cacutt, L.

Cairns, D.

Caputo, P.

Christ, M.

Cohen, E.

Connor, W.

Connor, W.
Thracian Peltasts and their Influence on Greek Warfare (Groningen, 1969).

Modern Warfare: A Study of Men, Weapons and Theories (London, 1973).

Athenian Red Figure Vases: The Classical Period (London, 1989).

An Intimate History of Killing: Face-to-Face Killing in Twentieth Century Warfare (London, 1999).

'Athenian Casualty Lists', Hesperia, Vol.33 (1964), pp.16-62.

'The Athenian Casualty Lists', $C Q$, Vol.19 (1969), pp.145-59.

Excursion to Hell: The Battle for Mount Longdon (London, 1991).

Her Majesty’s Vietnam Soldier (London, 1992).

Homo Necans: The Anthropology of Ancient Greek Sacrificial Ritual and Myth (London, 1983).

Psychology, (London, 2004).

Combat (London, 1992).

Aidōs: The Psychology and Ethics of Honour and Shame in Ancient Greek Literature (Oxford, 1993).

A Rumor of War (New York, 1977).

The Bad Citizen in Classical Athens (Cambridge, 2006).

'The High Cost of Andreia at Athens' in R. Rosen and I. Sluiter (eds.), Andreia: Studies in Manliness and Courage in Classical Antiquity (Boston, 2002), pp.144-65.

'Tribes, Festivals and Processions: Civic Ceremonial and Political Manipulation in Archaic Greece', JHS, Vol.107 (1987), pp.40-50.

'Early Greek Land Warfare as Symbolic Expression', $P \& P$, Vol.119 (1988), pp.3-29. 
Connor, W.

Connor, W.

Cooley, C.

Crowley, J.

Daly, R.

Deacy, S.

Dover, K.

du Picq, C. A.

Ehrenreich, B.

Finley, M.

Fisher, N.

Fisher, F.

Foxhall, L.

Gabriel, R.
'Civil Society, Dionysiac Festival and the Athenian Democracy' in J. Ober and C. Hedrick (eds.), Demokratia: A Conversation on Democracies Ancient and Modern (Princeton, 1996), pp.217-26.

'Festivals and Athenian Democracy' in M. Sakellariou (ed.), Colloque International: Démocratie Athénienne et Culture (Athens, 1996), pp.79-90.

Social Organization: A Study of the Larger Mind (London, 2005).

The Psychology of the Athenian Hoplite: The Culture of Combat in Classical Athens (Cambridge, 2012).

'Samuel Pepys and Post-Traumatic Stress Disorder', The British Journal of Psychiatry, Vol.143 ( 1983), pp.64-8.

'Athena and Ares: War, Violence and Warlike Deities' in H. van Wees (ed.), War and Violence in Ancient Greece (London, 2000), pp.285-298.

Greek Popular Morality in the Time of Plato and Aristotle (Oxford, 1974).

Battle Studies: Ancient and Modern Battle (Roots of Strategy Book 2: 3 Military Classics, Mechanicsburg, 1987).

Blood Rites: Origins and History of the Passions of War (London, 1997).

'War and Empire' in M. Finley (ed.), Ancient History: Evidence and Models (London, 1985), pp.67-87.

'Violence, Masculinity and the Law in Classical Athens' in L. Foxhall and J. Salmon (eds.), When Men Were Men: Masculinity, Power and Identity in Classical Antiquity (London, 1998), pp.6897.

Hybris: A Study in the Values of Honour and Shame in Ancient Greece (Warminster, 1992).

'Farming and Fighting in Ancient Greece' in J. Rich and G. Shipley (eds.), War and Society in the Greek World (London, 1995), pp.134-45.

Soldiers' Lives Through History: The Ancient World (London, 2007). 
Gabriel, R.

\& Metz, K.

Gabriel, R.

$\&$ Savage, P.

Garlan, Y.

Gersons, B.

\& Carlier, I.

Glenn, R.

Goldhill, S.

Goodman, M.

\& Holladay, A.

Gray, J.

Green, P.

Grossman, D.

Grossman, D. \& Christensen, L.

Gruen, E.

Grundy, G.

Hall, E.

Hanson, V.

Hanson, V.
From Sumer to Rome: The Military Capabilities of Ancient Armies (Westport, Connecticut, 1991).

Crisis in Command: Mismanagement in the Army (New York, 1978).

War in the Ancient World: A Social History (London, 1975).

'Post-Traumatic Stress Disorder: The History of a Recent

Concept', The British Journal of Psychiatry, Vol.161 (1992), pp.742-8.

Reading Athena's Dance Card: Men Against Fire in Vietnam (Annapolis, 2000).

'The Great Dionysia and Civic Ideology' in J. Winkler and F. Zeitlin (eds.), Nothing to Do With Dionysos?: Athenian Drama in its Social Context (Princeton, 1990), pp.97-129.

'Religious Scruples in Ancient Warfare', CQ, Vol.36 (1986), pp.151-71.

The Warriors: Reflections on Men in Battle (London, 1998).

'War and Morality in Fifth-Century Athens: The Case of Euripides' Trojan Women', AHB, Vol.13 (1999), pp.97-110.

On Killing: The Psychological Cost of Learning to Kill in War and Society (London, 1996).

On Combat: The Psychology of Deadly Conflict in War and Peace (New York, 2008).

Rethinking the Other in Antiquity (Princeton, 2011).

Thucydides and the History of his Age (London, 1911).

Inventing the Barbarian: Greek Self-Definition through Tragedy (Oxford, 1989).

'Hoplite Technology in Phalanx Battle' in V. Hanson (ed.), Hoplites: The Classical Greek Battle Experience (London, 1991), pp.63-84.

The Western Way of War: Infantry Battle in Classical Greece (London, 2000). 
Haughn C. 'The Book of Job: Implications for Construct Validity of \& Gonsiorek, J. Posttraumatic Stress Disorder Diagnostic Criteria', Mental Health, Religion and Culture, Vol.12 (2009), pp.833-45.

Hauser, W.

'The Will to Fight' in S. Sarkesian (ed.), Combat Effectiveness: Cohesion, Stress, and the Volunteer Military (London, 1980), pp.186-211.

Henderson, W. Cohesion: The Human Element in Combat: Leadership and Societal Influence in the Armies of the Soviet Union, the United States, North Vietnam, and Israel (Washington, 1985).

Herman, G.

'Treaties and Alliances in the World of Thucydides', PCPhS, Vol.36 (1990), pp.83-102.

Hogg, M. Social Psychology (Harlow, 2002).

\& Vaughan, G.

Hoiberg, A.

'Military Staying Power' in S. Sarkesian (ed.), Combat Effectiveness: Cohesion, Stress, and the Volunteer Military (London, 1980), pp.212-43.

Holmberg, E.

The Red-line Painter and the Workshop of the Acheloos Painter (Jonsered, 1990).

Holmes, R. $\quad$ Acts of War (London, 2003).

Hölscher, T. 'Images and Political Identity: The Case of Athens', in D. Boedeker and K. Raaflaub (eds.), Democracy, Empire, and the Arts in Fifth-Century Athens (London, 1998), pp.153-83.

Isaac, B.

The Invention of Racism in Classical Antiquity (Oxford, 2004).

Jackson, A.

'Hoplites and the Gods: The Dedication of Captured Arms and Armour' in V. Hanson (ed.), Hoplites: The Classical Greek Battle Experience (London, 1991), pp.228-49.

Jacoby, J.

'Patrios Nomos: State Burial in Athens and the Public Cemetery in the Kerameikos', JHS, Vol.64 (1944), pp.37-66.

Jameson, M. 'Sacrifice Before Battle' in V. Hanson (ed.), Hoplites: The Classical Greek Battle Experience (London, 1991), pp.197-227.

Jarva, E. Archaiologia on Archaic Greek Body Armour (Rovaniemi, 1995). 
Jones, N.

Karavites, P.

Keegan, J.

Keegan, J.

Kellet, A.

Koh, H.

Krentz, P.

Lazarus, R.

Lazarus, R.

Lazenby, J.

Lewy, G.

Liddel, $\mathrm{P}$.

Lissarrague, $\mathrm{F}$.

Loraux, N.

Low, P.
The Associations of Classical Athens: The Response to Democracy (Oxford, 1999).

'Greek Interstate Relations in the Fifth Century BC', $P P$, Vol.216 (1984), pp.161-92.

The Face of Battle: A Study of Agincourt, Waterloo and the Somme (London, 1976).

A History of Warfare (London, 1993).

Combat Motivation: The Behavior of Soldiers in Battle (London, 1982).

'Why Do Nations Obey International Law?', Yale Law Journal, Vol.106 (1997), pp.2599-659.

'Fighting by the Rules: The Invention of the Hoplite Agōn', Hesperia, Vol.71 (2002), pp.23-39.

Psychological Stress and the Coping Process (New York, 1966).

'Cognitive-motivational-relational theory of Emotion' in Y. Hanin (ed.), Emotions in Sport (Champaign, Illinois, 2000), pp.39-64.

'The Killing Zone' in V. Hanson (ed.), Hoplites: The Classical Greek Battle Experience (London, 1991), pp.87-109.

'The American Experience in Vietnam' in S. Sarkesian (ed.), Combat Effectiveness: Cohesion, Stress, and the Volunteer Military (London, 1980), pp.94-106.

Civic Obligation and Individual Liberty in Ancient Athens (Oxford, 2007).

'The World of the Warrior' in C. Bérard et al. (eds), A City of Images: Iconography and Society in Ancient Greece (Guildford, 1989), pp.39-51.

The Invention of Athens: The Funeral Oration in the Classical City (London, 1986).

Interstate Relations in Classical Greece: Morality and Power (Cambridge, 2007). 
Maguen, S. et al.

McManus, J.

MacNair, R.

March, C. \& Greenberg, N.

Marshall, S.

Matheson, S.

Matheson, S.

Maurizio, L.

Melchior, A.

Mitchell, L.

Momigliano, A.

Moore, B. \& Reger, G.
'The Impact of Reported Direct and Indirect Killing on Mental Health Symptoms in Iraq War Veterans', Journal of Traumatic Stress, Vol.23 (2010), pp.86-90.

The Deadly Brotherhood: The American Combat Soldier in World War II (Novato, California, 1998).

Perpetration-Induced Traumatic Stress: The Psychological Consequences of Killing (Westport, Connecticut, 2002).

'The Royal Marines' Approach to Psychological Trauma' in C. Figley and W. Nash (eds.), Combat Stress Injury: Theory, Research, and Management (London, 2007), pp.247-60.

Men Against Fire: The Problem of Battle Command (Oklahoma, 2000).

Polygnotos and Vase Painting in Classical Athens (London, 1995).

'A Farewell with Arms: Departing Warriors on Athenian Vases' in J. Barringer and J. Hurwit (eds.), Periklean Athens and its Legacy: Problems and Perspectives (Austin, 2005), pp.23-35.

'The Panathenaic Procession: Athens' Participatory Democracy on Display?' in D. Boedeker and K. Raaflaub (eds.), Democracy, Empire and the Arts in Fifth-Century Athens (London, 1998), pp.297-317.

'Caesar in Vietnam: Did Roman Soldiers Suffer from PostTraumatic Stress Disorder?’ G\&R, Vol.58 (2011), pp.209-33.

'Philia, Eunoia and Greek Interstate Relations', Antichthon, Vol.31 (1997), pp.28-44.

'Some Observations on Causes of War in Ancient Historiography' in A. Momigliano (ed.), Studies in Historiography (London, 1966), pp.112-26.

'Historical and Contemporary Perspectives of Combat Stress and the Army Combat Stress Control Team' in C. Figley and W. Nash (eds.), Combat Stress Injury: Theory, Research, and Management (London, 2007), pp.161-81.

MRCP
6-11C (Washington, 2000). 
Nash, W.

Nash, W.

Neils, J.

Ober, J.

Ober, J.

O’Brien, T.

Osborne, R.

Parker, R.

Pemberton, E.

Petrakos, B.

Phillipson, C.

Phillipson, C.

Popper, K.

Pritchard, D.

Pritchett, W.
'Combat/Operational Stress Adaptations and Injuries' in C. Figley and W. Nash (eds.), Combat Stress Injury: Theory, Research, and Management (London, 2007), pp.33-63.

'The Stressors of War' in C. Figley and W. Nash (eds.), Combat Stress Injury: Theory, Research, and Management (London, 2007), pp.11-31.

'The Panathenaia and Kleisthenic Ideology' in W. Coulson, O. Palagia, T. Shear, H. Shapiro and F. Frost (eds.), The Archaeology of Athens and Attica under the Democracy (Oxford, 1994), pp.15160 .

'The Rules of War in Classical Greece' in J. Ober (ed.), The Athenian Revolution: Essays on Ancient Greek Democracy and Political Theory (Princeton, 1996), pp.53-71.

Democracy and Knowledge: Innovation and Learning in Classical Athens (Oxford, 2008).

If I Die in a Combat Zone (London, 1995).

Demos: The Discovery of Classical Attika (London, 1985).

'Sacrifice and Battle' in H. van Wees (ed.), War and Violence in Ancient Greece (London, 2000), pp.299-314.

'The Name Vase of the Peleus Painter', The Journal of the Walters Art Gallery, Vol.36 (1977), pp.62-72.

'Anaskaphē Rhamnoūntos', Praktika tes en Athenais Archaiologikes Hetaireias, Vol.59 (1984), pp.197-8.

The International Law and Custom of Ancient Greece and Rome, Vol.I (London, 1911).

The International Law and Custom of Ancient Greece and Rome, Vol.II (London, 1911).

The Logic of Scientific Discovery (London, 1959).

'The Fractured Imaginary: Popular Thinking on Military Matters in Fifth Century Athens', AH, Vol.28 (1998), pp.38-61.

The Greek State at War, Part I (Berkeley, 1971). 
Pritchett, W.

Raaflaub, K.

Raaflaub, K.

Rademaker, A.

Richardson, F.

Roisman, J.

Roisman, J.

Runciman, W.

Sajer, G.

Sassoon, S.

Schatcher, S.

Schnurr, P.

Schnurr, P.

Schnurr, P.

Schwartz, A.
The Greek State at War: Part III (Berkeley, 1979).

'The Transformation of Athens in the Fifth Century' in D. Boedeker and K. Raaflaub (eds.), Democracy, Empire and the Arts in Fifth-Century Athens (London, 1998), pp.15-41.

'Father of All, Destroyer of All: War in Late Fifth-Century Athenian Discourse and Ideology' in D. McCann and B. Strauss (eds.), War and Democracy: A Comparative Study of the Korean War and the Peloponnesian War (London, 2001), pp.307-56.

"Most Citizens are Europrôktoi Now": (Un)manliness in Aristophanes' in R. Rosen and I. Sluiter (eds.), Andreia: Studies in Manliness and Courage in Classical Antiquity (Boston, 2002), pp.115-25.

Fighting Spirit: A Study of the Psychological Factors in War (London, 1978).

'The Rhetoric of Courage in the Athenian Orators' in R. Rosen and I. Sluiter (eds.), Andreia: Studies in Manliness and Courage in Classical Antiquity (Boston, 2002), pp.126-43.

The Rhetoric of Manhood: Masculinity in the Attic Orators (London, 2005).

'Greek Hoplites, Warrior Culture, and Indirect Bias', The Journal of the Royal Anthropological Institute, Vol.4 (1998), pp.731-51.

The Forgotten Soldier (London, 1991).

Memoirs of an Infantry Officer (London, 1966).

The Psychology of Affiliation (Stanford, California, 1959).

'The First 20 Years', Journal of Traumatic Stress, Vol.21 (2008), pp.1-2.

'The Changing Face of PTSD Diagnosis', Journal of Traumatic Stress, Vol.22 (2009), pp.1-2.

'PTSD 30 Years On', Journal of Traumatic Stress, Vol.23 (2010), pp.1-2.

Reinstating the Hoplite: Arms, Armour and Phalanx Fighting in Archaic and Classical Greece (Stuttgart, 2009). 
Sekunda, N.

Shalit, B.

Shay, J.

Shay, J.

Sheets, G.

Shephard, B.

Shils, E.

\& Janowitz, M.

Snodgrass, A.

Sorley, L.

Spira, J., Pyne, J. \& Wiederhold, B.

Strauss, B.

Stouffer, S. et al.

Stouffer, S. et al.

Struve, L.

Summerfield, D.
'Athenian Demography and Military Strength 338 - 322 BC', ABSA, Vol.87 (1992), pp.311-55.

The Psychology of Conflict and Combat (London, 1988).

Achilles in Vietnam: Combat Trauma and the Undoing of Character (New York, 1995).

Odysseus in America: Combat Trauma and the Trials of Homecoming (New York, 2002).

'Conceptualising International Law in Thucydides', $A J P h$, Vol.115 (1994), pp.51-73.

A War of Nerves: Soldiers and Psychiatrists in the Twentieth Century (Cambridge, Massachusetts, 2001).

'Cohesion and Disintegration in the Wehrmacht in World War II', Public Opinion Quarterly, Vol.12 (1948), pp.280-315.

Arms and Armour of the Greeks (London, 1967).

'Prevailing Criteria: A Critique' in S. Sarkesian (ed.), Combat Effectiveness: Cohesion, Stress, and the Volunteer Military (London, 1980), pp.57-93.

'Experiential Methods in the Treatment of Combat PTSD' in C.

Figley and W. Nash (eds.), Combat Stress Injury: Theory, Research, and Management (London, 2007), pp.205-18.

'Naval Battles and Sieges' in P. Sabin, H. van Wees, and M. Whitby (eds.), The Cambridge History of Greek and Roman Warfare, Volume I. (Cambridge, 2007), pp.223-47.

Studies in Social Psychology in World War Two, Volume I: The American Soldier: Adjustment during Army Life (Princeton, 1949).

Studies in Social Psychology in World War Two, Volume II: The American Soldier: Combat and its Aftermath (Princeton, 1949).

'Confucian PTSD: Reading Trauma in a Chinese Youngster's Memoir of 1653', History and Memory, Vol.16 (2004), pp.14-31.

'A Critique of Seven Assumptions behind Psychological Trauma Programmes in War-affected Areas', Social Science and Medicine, Vol.48 (1999), pp.1449-62. 
Szalma, J.

Tod, M.

Trimble, $\mathrm{M}$.

Tritle, L.

Tritle, L.

Trotter, W.

van Creveld, $\mathrm{M}$.

van Creveld, M.

van Wees, $\mathrm{H}$.

van Zanten, W.

Villing, A.

Watson, P.

Wesbrook, S.

Wheeler, E.

Wilson, C.
'Individual Differences in Stress Reaction' in P. Hancock and J. Szalma (eds.), Performance under Stress (Burlington, Vermont, 2008), pp.323-57.

International Arbitration Amongst the Greeks (Oxford, 1913).

'Post-traumatic Stress Disorder: History of a Concept', in C. Figley (ed.), Trauma and its Wake I: The Study and Treatment of Post-Traumatic Stress Disorder (New York, 1985), pp.5-14.

'Hector's Body: Mutilation of the Dead in Ancient Greece and Vietnam', $A H B$, Vol.11 (1997), pp.123-36.

From Melos to My Lai: War and Survival (London, 2000).

Instincts of the Herd in Peace and War (London, 1921).

Fighting Power: German and U.S. Army Performance, 1939-1945 (Westport, 1982).

'Technology and War II: From Nuclear Stalemate to Terrorism' in Charles Townshend (ed.), The Oxford History of Modern War (Oxford, 2005), pp.341-63.

Greek Warfare: Myths and Realities (London, 2004).

Don't Bunch Up (and Some Notable Exceptions): One Marine's Story (Connecticut, 1993).

The Iconography of Athena in Attic Vase-painting from 440 BC 370 BC (Oxford MPhil, 1992).

War on the Mind: The Military Uses and Abuses of Psychology (Harmondsworth, 1980).

'The Potential for Military Disintegration' in S. Sarkesian (ed.), Combat Effectiveness: Cohesion, Stress, and the Volunteer Military (London, 1980), pp.244-78.

'Land Battles' in P. Sabin, H. van Wees and M. Whitby (eds.), The Cambridge History of Greek and Roman Warfare, Volume I (Cambridge, 2007), pp.186-223.

The Anatomy of Courage (London, 1987). 
Whitehead, D. The Demes of Attica 508/7 - ca. 250 BC: A Political and Social Study (Princeton, 1986).

Worley, L.

Hippeis: The Cavalry of Ancient Greece (Oxford, 1994).

Wyse, W.

The Speeches of Isaeus (Cambridge, 1904).

Yoshitake, S. 'Aretē and the Achievements of the War Dead: The Logic of Praise in the Athenian Funeral Oration' in D. Pritchard (ed.), War, Democracy and Culture in Classical Athens (Cambridge, 2010), pp.359-77.

Zampaglione, G. The Idea of Peace in Antiquity (London, 1973). 